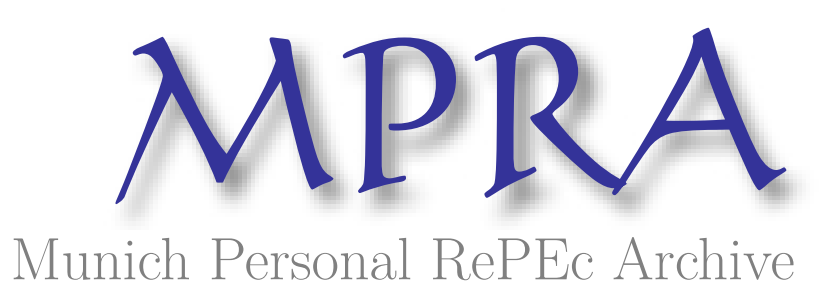

\title{
How do Firm Characteristics Affect Capital Structure? Some UK Evidence.
}

\author{
Akdal, Sinan \\ Kingston University, London
}

4 October 2010

Online at https://mpra.ub.uni-muenchen.de/29199/

MPRA Paper No. 29199, posted 08 Mar 2011 01:01 UTC 


\section{How do Firm Characteristics Affect Capital Structure? Some UK Evidence}

Sinan AKDAL 


\begin{abstract}
$\underline{\text { Abstract }}$
This study aims to determine the influence of various firm level characteristics such as, profitability, size, growth opportunities, asset tangibility, non-debt tax shield, volatility and liquidity on capital structure. Employing the cross-sectional data methodology, the researcher examines the capital structure determinants of 202 companies from FTSE 250 for the time period of $2002-2009$. Seven variables multiple regression models are used to estimate the influence of firm level attributes on capital structure and capital structure is measured simultaneously by the ratios of total debt, long-term debt and short-term debt at both book value and market value of equity. The results obtained from four different regression models show that profitability and liquidity are negatively and significantly related to leverage. Also asset tangibility has a positive relationship with leverage, which is significant. Moreover the researcher finds that total debt ratio at market value of equity is the most important dependent variable as a proxy of capital structure, followed by long-term debt ratio at market value of equity.
\end{abstract}




\section{DECLARATION}

I declare that this dissertation is all my own work and the sources of information and material I have used (including the Internet) have been fully identified and properly acknowledged as required.

I have kept all materials used in this research, including samples, research data, preliminary analysis, notes and drafts, and I can produce them on request. 


\section{$\underline{\text { Acknowledgement }}$}

I would like to show my gratitude to everybody who has helped me throughout the research period.

First, my hearty thanks to my supervisor Dr Natalia Isachenkova for her valuable comments and guidance during this research study. I also thank all eminent faculty members for their help and teaching throughout the course.

Though words do not suffice, I would also like to thank my mum, my dad and my sister.

They have been caring, patient and positive during my time at Kingston University. It would not have been possible to write this dissertation without the help and support of them. Their love and support will always be appreciated and never forgotten. 


\section{List of Contents}

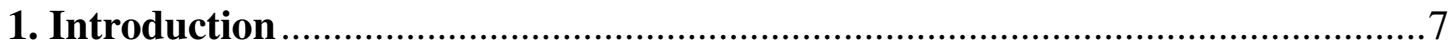

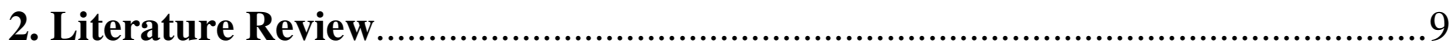

2.1 Financial Distress and Trade-off Theory …………….....................................

2.2 Pecking Order Theory ................................................................................. 10

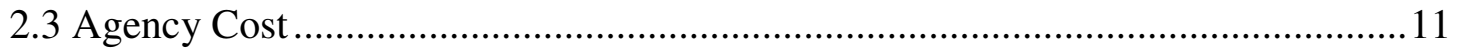

2.4 Past Empirical Studies .................................................................................12

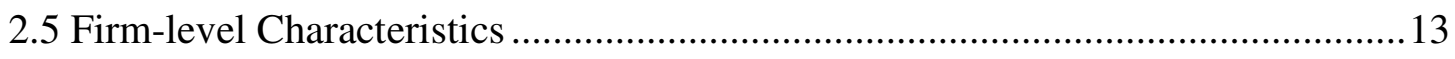

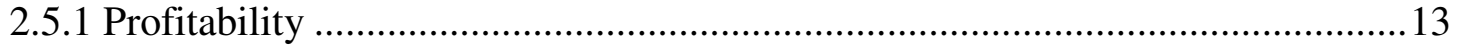

2.5.2 Size

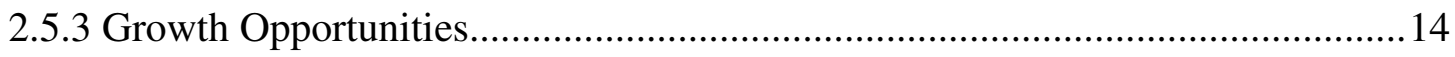

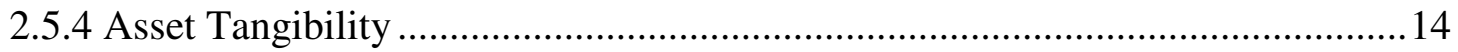

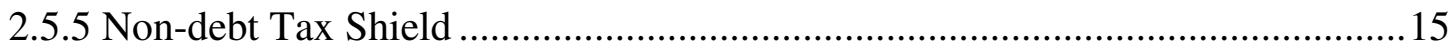

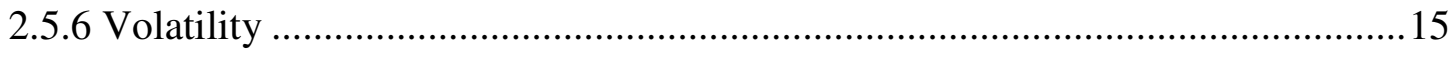

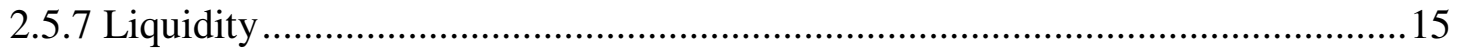

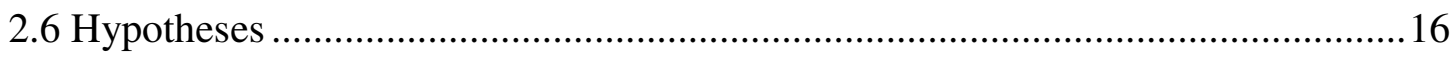

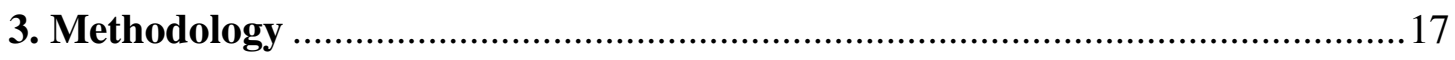

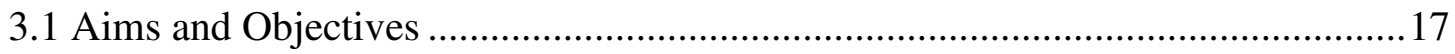

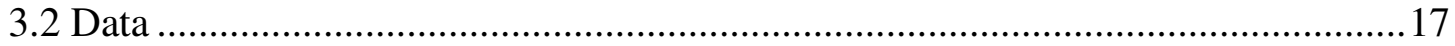

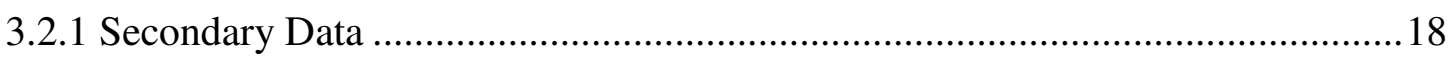

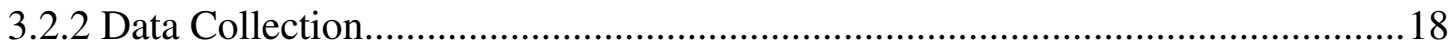

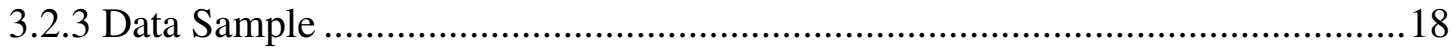

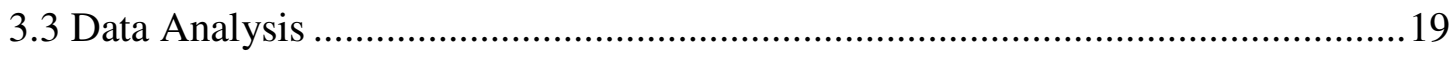

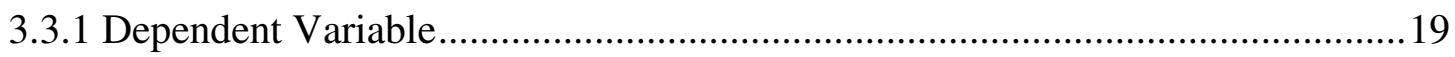

3.3.2 Independent Variables.....................................................................................19

3.3.3 Model Specification .....................................................................................19

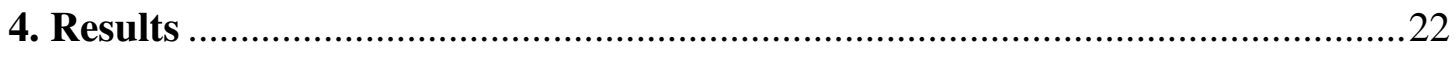

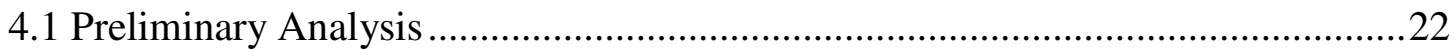

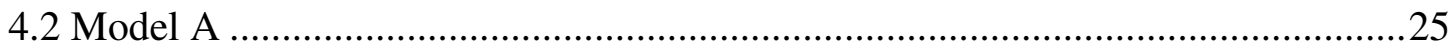

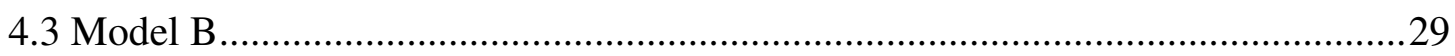




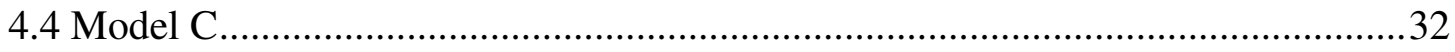

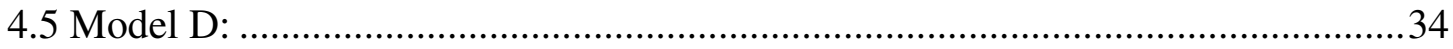

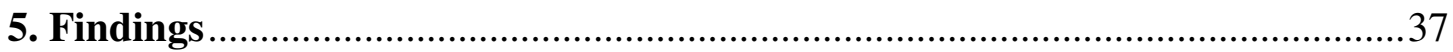

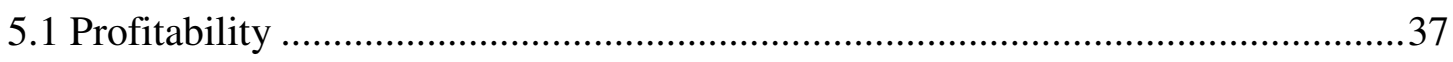

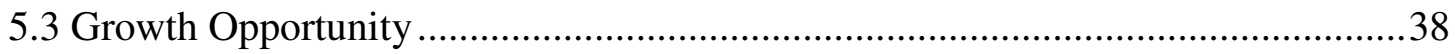

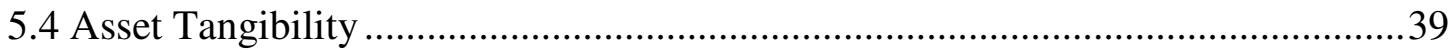

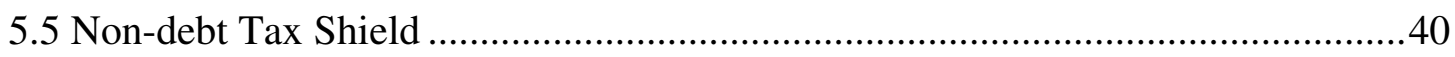

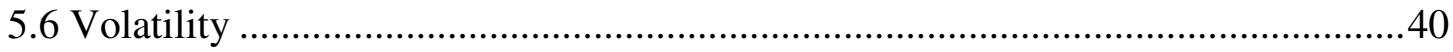

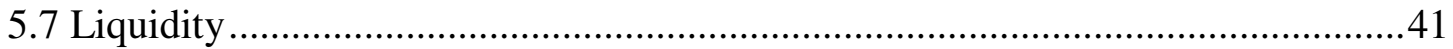

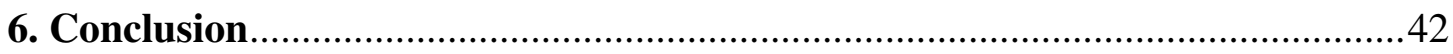

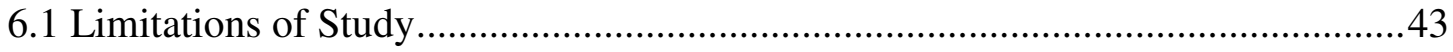

6.2 Recommendation for Further Research ..........................................................44

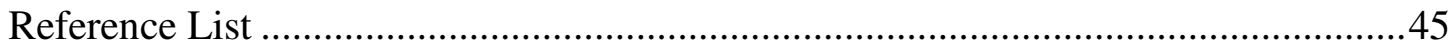

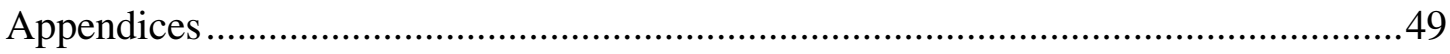

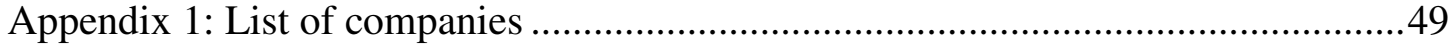


Table 1: Past Empirical Studies...................................................11

Table 2: Hypotheses......................................................... 16

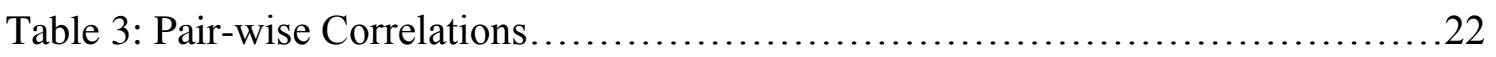

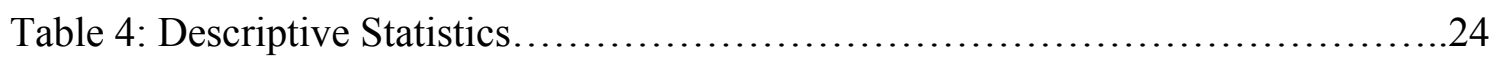

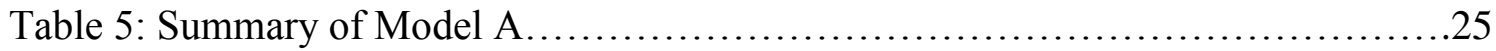

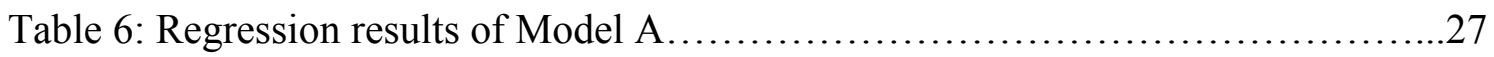

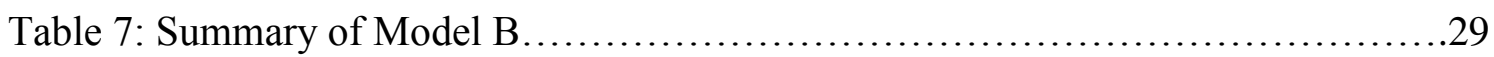

Table 8: Regression results of Model B..............................................

Table 9: Summary of Model C .................................................. 33

Table 10: Regression results of Model C........................................ 35

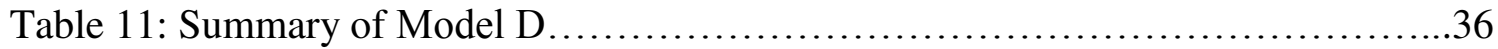

Table 12: Regression results of Model D ........................................ 


\section{Introduction}

Capital structure has been one of the most broadly argued subjects in corporate finance. Since the study of Modigliani and Miller (1958), the question has been raised that how the mixture of debt and equity in capital structure affects the firm value. Also the factors that can have impacts on firm's capital structure are very argumentative subject in the finance literature.

So far there have been many studies conducted on determinants of capital structure and these papers try to investigate the significant correlations between capital structure and possible firm specific characteristic having impact on it. These studies have been started with the seminal paper of Modigliani and Miller (1958) and researchers still carry on identifying the determinants of capital structure with latest and different methods. In this paper, researcher analyses capital structure and its determinants for 202 listed UK companies over the time period from 2002 to 2009. The aim of this paper is to investigate whether there is a significant correlation between the capital structure and firm-level characteristics such as profitability, size, growth opportunities, asset tangibility (asset structure), non-debt tax shield, volatility (risk), liquidity and time dummies to extend the past studies which have been conducted in 2000s.

The focus of this research is to answer following question;

Is there a significant correlation between the capital structure and firm-level characteristics (profitability, size, growth, tangibility, non-debt tax shield, volatility and liquidity) of capital structure in listed UK companies?

The data, which was collected from secondary sources, are subject to analysis based on pooled ordinary least squares (OLS) model. OLS method has been used in study of Ozkan (2001) and Bennett and Donnelly (2003) which examined the relationship between leverage and dependent variables, such as profitability, size, growth, tangibility, non-debt tax shield, volatility and liquidity.

In the literature review, Section 2, the background of fundamental theories of capital structure and the past studies done on the relevant subject is provided. Section 3 presents the aim and objectives, research methodology and explains the data sample and data collection and describes dependent and independent variables as named above. Section 4 presents the preliminary analysis of data sample, descriptive statistics and results 
obtained from regression models (Model A, Model B, Model C and Model D). Section 5 includes eight subsections for each independent variable. In these sections, results from different regression models are incorporated with past empirical studies' results and capital structure theories. In conclusion, section 6 , consists of the summary this paper, findings, limitation of study and recommendation for further study. 


\section{Literature Review}

Capital structure can be defined as the mixture of firm's capital with debt and equity and it has been one of the most argumentative subjects in corporate finance, since the outstanding study of Modigliani and Miller in 1958 (Bevan and Danbolt, 2004). Many theories have been developed in the literature for examining determinants of capital structure and they focus on which determinants are more likely to have a major role on the leverage decisions. However, it is still debated what the determinants of capital structure are and how they impact capital structure decisions, even though there have been various studies conducted on the relevant subject. In this paper, the researcher intends to review fundamental capital structure theories briefly and give past empirical studies on determinants of capital structure.

\subsection{Financial Distress and Trade-off Theory}

Financial distress has an important position in capital structure theories. Berk and DeMarzo (2007, p. 509) define financial cost as 'when a firm has trouble meeting its debt obligations we say the firm is in financial distress'. When a firm increases its proportion of debt to equity for financing its operations and future investments, the probability of default on the debt will raise as well (Kraus and Litzenberger, 1973). The cost arising from financial distress plays crucial role on the firm's future decisions such as, investment policy, cuts in research and development activities, advertisement and educational expenditures (Warner, 1977). All these decisions as an outcome of financial distress will affect firm's value negatively and lead to decline in the firm's value; therefore the wealth of shareholders will decrease as well (Arnold, 2008).

There are two types of costs arising from financial distress, direct and indirect cost. Direct costs are bankruptcy fee, administrative fee and legal costs as well (Warner, 1977). Indirect costs arise from firm's decision-makings due to financial distress. These are, as mentioned above, changes in investment policy such as, postponing future positive NPV investments or totally discarding investment opportunity, decrease in staff educational expenditures and reducing research and development and marketing activities (Arnold, 2008).

The trade-off theory states that interest tax shield and cost of bankruptcy (financial distress) plays crucial role on firm's leveraged ratio. This theory suggest that the total 
value of a geared firm equals the value of the ungeared firm plus present value of the interest tax shield, minus the present value of financial cost (Berk and DeMarzo, 2007). Therefore the firm looks for optimum debt ratio, which offsets tax savings benefits opposing to the cost of possible bankruptcy and agency conflict (Gajurel, 2005).

According to the trade-off theory, companies that make high profits are more likely to have higher leverage and more taxable income to shield (Barclay and Smith, 2005). However, Rajan and Zingales (1995) study shows that this theory fails in some cases to illuminate why profitable firms have low debt ratio. Also Bevan and Danbolt (2002) suggest that the trade-off theory has some shortcomings and limitations. In addition to these empirical studies of Kester (1986) and Titman and Wessels (1988), which supports that, there is strong inverse correlation between profitability and debt ratios in capital structure. As a result, due to shortcomings and flaws of trade-off theory, the theory is not adequate when determining the ideal capital structure.

\subsection{Pecking Order Theory}

Myers and Majluf (1984) proposed the pecking order theory that firms would prefer retained earnings as a primary source of internal financing. If internal financing does not meet the requirements, then firms prefer external financing by issuing securities. According to Myers (1984), if the firm is need of using external finance, firm chooses first the safest security (debt market) to issue rather than convertible bonds. As a last choice, the firm recourses equity market and issue external equity.

The firm that has not enough available internal finance would either use equity or debt issue to finance future positive NPV investments. According to Myers and Majluf (1984), issuing external equity gives a bad signal to the market that supporting equity is overrated. Nevertheless issuing debt sends a signal supporting stock is underestimated. This conflict 'leads to an interaction between investment and financing decision' (Gajurel, 2005, p. 19).

The pecking order theory suggests that there is no exact target level of leverage and interest tax shield and financial distress are considered as less effective factors when determining capital structure decisions (Myers, 2001). Also he further advocates that trade-off theory does not differentiate finance equities as external and internal and states that there is a positive correlation between profitability and debt ratio. Nevertheless, 
pecking order theory advocates a negatively correlated relationship and Myers and Majluf (1984) suggest less profitable firms are more like to borrow more debt to finance future positive NPV investments; therefore the firm will raise its profitability. In addition to this, the studies of Ozkan (2001), Kester (1986) and Titman and Wessels (1988) support inverse relationship between leverage and profitability. As a result, pecking order theory is much more accurate in order to explain reverse relationship of profitability and debt ratios rather than trade-off theory.

\subsection{Agency Cost}

Jensen and Meckling (1976) defined agency costs as examining conflicts and relationships between the agent (corporate managers) and principals (shareholders). The opposed interests of principals and agents and separation of management and ownership in a firm cause these conflicts. For instance, managers may be interested in taking negative NPV projects or making unnecessary acquisitions by paying too much to increase size and reputation of the firm instead of maximising the wealth of shareholders. The explanation behind this is the agents are more likely to run and control bigger firms than smaller ones. Hence the managers will receive higher salaries and remuneration packages as a result of increasing size of the firm (Berk and DeMarzo, 2007). In conclusion, managers may tend to operate the firm in consistent with their interest rather than taking into consideration of increasing the firm value and wealth of shareholders.

Harris and Raviv (1991) and Jensen (1986) describe two types of conflicts, the agency cost of equity and the agency cost of debt. The agency cost of equity, as mentioned above, is between shareholders and managers and small firms generally do not suffer from this cost since they are mostly operated by owners (Easterbrook, 1984). This cost emerges from management board's different interests, which are not corresponded to maximising stockholder wealth. The agency cost of debt is between equity holders and debt holders and this conflict arises from risk shifting which means transferring risk from debt holders to equity holders by making risky investments with debt (Jensen, 1986).

Jensen (1986) also states that a firm, which has high levels of excess cash, is more likely to experience agency cost. When excess cash is reducing and debt is increasing, it would 
limit the availability of money for future investments and spending. Hence managers tend to manage firm more attentively not to face financial distress and this decreases possibility of experiencing agency cost. According to Harris and Raviv (1991) study, leverage is used as a tool for providing motivation and discipline for management and minimising agency cost.

In conclusion, Harris and Raviv (1991) further state that there is a positive relationship between leverage and free cash flow, company value and liquidity.

\subsection{Past Empirical Studies}

When the past empirical studies are analysed, there is still no generally accepted model on determinants of capital structure. Each researcher takes into consideration different determinants that impact the level of debt ratio. Some prominent and recent studies are listed on Table 1. 
Table 1: Past Empirical Studies

\begin{tabular}{|c|c|c|c|c|c|}
\hline Resarch & Data Period & Focus & $\begin{array}{l}\text { Sample } \\
\text { Size }\end{array}$ & $\begin{array}{c}\text { Profitability (P) } \\
\text { Size (S) } \\
\text { Growth }(\mathbf{G}) \\
\text { Tangibility (T) } \\
\text { Non-debt Tax Shield } \\
\text { (TS) } \\
\text { Volatility (V) }\end{array}$ & Other Determinants \\
\hline Wald (1999) & 1993 & $\begin{array}{c}\text { French, German, UK } \\
\text { and Japanese } \\
\text { Companies }\end{array}$ & 4404 & $\mathrm{P}, \mathrm{S}, \mathrm{G}, \mathrm{T}, \mathrm{TS}, \mathrm{V}$ & $\begin{array}{c}\text { Moral Hazard } \\
\text { Bankruptcy Cost }\end{array}$ \\
\hline $\begin{array}{c}\text { Bevan and } \\
\text { Danbolt (2000) }\end{array}$ & 1991-1997 & $\begin{array}{c}\text { Non-financial UK } \\
\text { companies }\end{array}$ & 1054 & $\mathrm{P}, \mathrm{S}, \mathrm{G}, \mathrm{T}$ & \\
\hline Ozkan (2001) & 1984-1996 & $\begin{array}{l}\text { Non-financial UK } \\
\text { Companies }\end{array}$ & 390 & $\mathrm{P}, \mathrm{S}, \mathrm{G}, \mathrm{TS}$ & \\
\hline $\begin{array}{c}\text { Bevan and } \\
\text { Danbolt (2002) }\end{array}$ & 2001-2002 & $\begin{array}{l}\text { European } \\
\text { Companies }\end{array}$ & 710 & $\mathrm{~S}, \mathrm{~V}$ & $\begin{array}{c}\text { Industry Effect } \\
\text { Investment Grade } \\
\text { Level of Foreign Sales } \\
\text { Credit Rating }\end{array}$ \\
\hline Chen (2003) & $1995-2000$ & $\begin{array}{l}\text { Listed Chinese } \\
\text { Companies }\end{array}$ & 88 & $\mathrm{P}, \mathrm{S}, \mathrm{G}, \mathrm{T}$ & \\
\hline Gaud et al. (2003) & $1991-2000$ & $\begin{array}{l}\text { Listed Swiss } \\
\text { Companies }\end{array}$ & 106 & $\mathrm{P}, \mathrm{S}, \mathrm{G}, \mathrm{T}, \mathrm{V}$ & \\
\hline $\begin{array}{c}\text { Sahh and Hijazi } \\
\text { (2004) }\end{array}$ & $1997-2001$ & $\begin{array}{c}\text { Non-financial } \\
\text { Pakistani Companies }\end{array}$ & 445 & $\mathrm{P}, \mathrm{S}, \mathrm{G}, \mathrm{T}$ & \\
\hline Bauer (2004) & $2000-2001$ & Czech Companies & 74 & $\mathrm{P}, \mathrm{S}, \mathrm{G}, \mathrm{T}, \mathrm{TS}$ & \\
\hline Song (2005) & $1992-2000$ & Swedish Companies & 6000 & $\mathrm{P}, \mathrm{S}, \mathrm{G}, \mathrm{T}, \mathrm{TS}$ & \\
\hline $\begin{array}{l}\text { Eriotis et al. } \\
\quad(2007)\end{array}$ & $1997-2001$ & $\begin{array}{l}\text { Listed Greek } \\
\text { Companies }\end{array}$ & 129 & $S, G$ & $\begin{array}{c}\text { Quick Ratio } \\
\text { Interest Coverage Ratio }\end{array}$ \\
\hline $\begin{array}{l}\text { Chang and Lee } \\
\text { (2008) }\end{array}$ & $1988-2003$ & Various Campanies & 351 & $\mathrm{P}, \mathrm{G}, \mathrm{TS}$ & $\begin{array}{c}\text { Uniqueness } \\
\text { Collateral Value }\end{array}$ \\
\hline $\begin{array}{l}\text { Dragota and } \\
\text { Semenescu }\end{array}$ & $1997-2005$ & $\begin{array}{c}\text { Romanian Listed } \\
\text { Companies }\end{array}$ & 54 & $\mathrm{P}, \mathrm{S}, \mathrm{G}, \mathrm{T}$ & \\
\hline
\end{tabular}


(2008)

\begin{tabular}{|c|c|c|c|c|c|}
\hline $\begin{array}{c}\text { Psillaki and } \\
\text { Daskalakis (2008) }\end{array}$ & $1998-2002$ & $\begin{array}{c}\text { SMEs from Greece, } \\
\text { France, Italy and } \\
\text { Portugal }\end{array}$ & 3630 & $\mathrm{P}, \mathrm{S}, \mathrm{G}, \mathrm{T}, \mathrm{V}$ & \\
\hline $\begin{array}{l}\text { Deari and Deari } \\
\text { (2009) }\end{array}$ & 2005-2007 & $\begin{array}{l}\text { Listed and Unlisted } \\
\text { Macedonian } \\
\text { Companies }\end{array}$ & 32 & $\mathrm{P}, \mathrm{S}, \mathrm{G}, \mathrm{T}, \mathrm{TS}$ & \\
\hline $\begin{array}{l}\text { Liu and Ren } \\
\text { (2009) }\end{array}$ & 2004-2007 & $\begin{array}{l}\text { Listed Chinese IT } \\
\text { Companies }\end{array}$ & 92 & $\mathrm{P}, \mathrm{S}, \mathrm{G}, \mathrm{T}$ & Liquidity \\
\hline Abor (2009) & $1998-2003$ & Ghanaian Firms & 230 & $\mathrm{P}, \mathrm{S}, \mathrm{G}, \mathrm{T}$ & Dividend \\
\hline $\begin{array}{l}\text { Brinkhuis and } \\
\text { Maeseneire } \\
\text { (2009) }\end{array}$ & $2000-2007$ & $\begin{array}{l}\text { European } \\
\text { Companies }\end{array}$ & 126 & $\mathrm{P}, \mathrm{S}, \mathrm{G}, \mathrm{TS}$ & Collateral Value of Assets \\
\hline $\begin{array}{c}\text { Céspedes, } \\
\text { González and } \\
\text { Molina (2009) }\end{array}$ & $1996-2005$ & $\begin{array}{l}\text { Latin American } \\
\text { Firms }\end{array}$ & 1168 & $\mathrm{P}, \mathrm{S}, \mathrm{G}, \mathrm{TS}$ & Ownership Concentration \\
\hline $\begin{array}{c}\text { Vasiliou and } \\
\text { Daskalakis (2009) }\end{array}$ & $2002-2003$ & $\begin{array}{l}\text { Listed firms at the } \\
\text { Athens Exchange }\end{array}$ & 89 & $\mathrm{TS}$ & $\begin{array}{l}\text { Uniqueness } \\
\text { Industry }\end{array}$ \\
\hline Oztekin (2009) & $1991-2006$ & $\begin{array}{c}\text { Non-financial firms } \\
\text { in the Compustat } \\
\text { Global Vantage } \\
\text { Database }\end{array}$ & 15177 & $\mathrm{~S}, \mathrm{~T}$ & $\begin{array}{c}\text { Liquidity } \\
\text { Research and Development }\end{array}$ \\
\hline Ramlall (2009) & 2005-2006 & $\begin{array}{c}\text { Non-listed and non- } \\
\text { financial firms in } \\
\text { Mauritius }\end{array}$ & 450 & $\mathrm{P}, \mathrm{S}, \mathrm{G}, \mathrm{T}, \mathrm{TS}$ & $\begin{array}{l}\text { Liquidity } \\
\text { Age }\end{array}$ \\
\hline $\begin{array}{c}\text { Ramachandran } \\
\text { and Packkirisamy } \\
\text { (2010) }\end{array}$ & 1996-2007 & Indian Companies & 73 & $\mathrm{P}, \mathrm{S}$ & Dividend Payout \\
\hline
\end{tabular}




\subsection{Firm-level Characteristics}

Past researches (Vasiliou and Daskalakis (2009), Ramlall (2009) and Oztekin (2009)) on determinants of capital structure used some characteristics such as, profitability, size, growth, tangibility (asset structure), non-debt tax shield, volatility (risk), product uniqueness, time dummies, income variability, industry, ownership structure and liquidity. In this research, the most common and affecting determinants; profitability, size, growth, tangibility, non-debt tax shield, volatility, liquidity and time dummies are suggested as independent variables.

\subsubsection{Profitability}

From the past studies listed on Table 1 have found that profitability plays the most crucial role as a determinant of capital structure. Also past studies done by Ozkan (2001), Gaud et al. (2003), Bevan and Danbolt (2002) show a strong inverse relationship between debt ratio and profitability. The ratio of earning before interest, tax and depreciation (EBITDA), to total assets is assumed as measure to profitability.

Profitability $=$ EBITDA $/$ Total Assets

Hypothesis 1:

H0: There is a negative relationship between profitability and leverage $\mathrm{H} 1$ : There is a positive relationship between profitability and leverage

\subsubsection{Size}

According to Rajan and Zingales (1995) and Ozkan (2001), there is positive relationship between size and leverage. However Bevan and Danbolt (2000) found significant negative relationship between size and short-term debt ratio. Also Rajan and Zingales (1995) further state that the effect of size on short-term and long-term debt ratio is unclear and inconclusive. Hence, in this paper the relationship between size and leverage is investigated according to following hypotheses.

Size $=$ Natural Logarithm of Sales [ln (Sales)]

Hypothesis 2A:

$\mathrm{H} 0$ : There is a positive relationship between size and leverage

$\mathrm{H} 1$ : There is a negative relationship between size and leverage

Hypothesis 2B: 
H0: There is a positive relationship between size and long-term leverage $\mathrm{H1}$ : There is a negative relationship between size and long-term leverage Hypothesis 2C:

H0: There is a positive relationship between size and short-term leverage H1: There is a negative relationship between size and short-term leverage

\subsubsection{Growth Opportunity}

Growth opportunity can be defined in several ways, thus past studies have taken into account different measures for growth. In this paper, in the line with Rajan and Zingales (2005), Bevan and Danbolt (2000) and Gaud et al. (2003) market to book ratio is used as a proxy for growth opportunity.

Growth Opportunity $=$ Market to Book Ratio

Hypothesis 3:

H0: There is a negative relationship between growth opportunity and leverage H1: There is a positive relationship between growth opportunity and leverage

\subsubsection{Asset Tangibility}

Jensen and Meckling (1976) proposed that asset tangibility is positively correlated with debt ratio and some other researchers, Bennett and Donnelly (2003), Rajan and Zingales (1995) and Gaud et al. (2003), have found evidences that support this correlation. On the other hand, Bevan and Danbolt (2000) and Psillaki and Daskalakis (2008) stated that there is negative relationship between asset tangibility and leverage. To investigate this relationship in both terms of long-term and short-term, following hypotheses are tested. Asset Tangibility $=$ Fixed Assets $/$ Total Assets

Hypothesis 4A:

H0: There is a positive relationship between asset tangibility and leverage $\mathrm{H} 1$ : There is a negative relationship between asset tangibility and leverage Hypothesis 4B:

H0: There is a positive relationship between asset tangibility and long-term leverage $\mathrm{H} 1$ : There is a negative relationship between asset tangibility and long-term leverage Hypothesis 4C:

H0: There is a positive relationship between asset tangibility and short-term leverage 
H1: There is a negative relationship between asset tangibility and short-term leverage

\subsubsection{Non-debt Tax Shield}

According to past studies done by Ozkan (2001), Wald (1999) and Bennett and Donnelly (1993), evidences have been found that there is negative relationship between non-debt tax shield (NDTS) and leverage. To examine this relationship, the proportion of annual depreciation to total assets is used as a proxy for NDTS.

NDTS = Annual Depreciation / Total Assets

Hypothesis 5:

H0: There is a negative relationship between NDTS and leverage

H1: There is a positive relationship between NDTS and leverage

\subsubsection{Volatility}

Psillaki and Daskalakis (2008) have found negative relationship between volatility and leverage. Contrary, Bennett and Donnelly (1993) have found evidences supporting positive relationship between them. As Titman and Wessels (1988) stated, standard deviation of EBITDA is used as a proxy of volatility. This paper examines this relation ship with the following hypothesis.

Volatility $=$ Standard Deviation of EBITDA

Hypothesis 6:

H0: There is a negative relationship between volatility and leverage

H1: There is a positive relationship between volatility and leverage

\subsubsection{Liquidity}

Ozkan (2001) suggests that liquidity has ambiguous effect on the capital structure decisions. In the line with study of Ozkan (2001), the proportion of current assets to current liabilities is chosen as a proxy for liquidity.

Liquidity $=$ Current Assets $/$ Current Liabilities

Hypothesis 7:

H0: There is a negative relationship between liquidity and leverage $\mathrm{H} 1$ : There is a positive relationship between liquidity and leverage 


\subsection{Hypotheses}

The summary of hypotheses, which have been proposed in the literature review as showed on following table.

Table 2: Hypotheses

\section{Hypothesis}

Profitability $\mathrm{H} 1: \quad$ There is a negative relationship between profitability and leverage

H2A: $\quad$ There is a positive relationship between size and leverage

Size H2B: There is a positive relationship between size and long-term leverage $\mathrm{H} 2 \mathrm{C}$ : $\quad$ There is a positive relationship between size and short-term leverage

Growth H3: There is a negative relationship between growth and leverage

H4A: $\quad$ There is positive relationship between tangibility and leverage

Tangibility H4B: There is positive relationship between tangibility and long-term leverage $\mathrm{H} 4 \mathrm{C}$ : There is positive relationship between tangibility and short-term leverage

Non-debt H5: There is a negative relationship between NDTS and leverage
Tax Shield

Volatility H6: There is a negative relationship between volatility and leverage

Liquidity H7: There is a negative relationship between liquidity and leverage 


\section{Methodology}

Past researches on determinants of capital structure mostly based on positivist approach and this paper will be prepared under the positivist paradigm. This paper intends to identify determinants of UK firms' capital structure by using regression analysis in SPSS. It also tries to examine the correlations between leverage and possible determinants.

\subsection{Aims and Objectives}

The aim of this paper is to investigate whether there is a significant correlation between the capital structure and firm-level characteristics, such as profitability, size, growth opportunity, asset tangibility (asset structure), non-debt tax shield, volatility (risk), product uniqueness, time dummies, income variability, industry, ownership structure and liquidity. In this paper, profitability, size, growth opportunity, asset tangibility, non-debt tax shield, volatility and liquidity are suggested as independent variables. Thus, the dependent variable is expressed as a function of these variables, Leverage $=\mathrm{f}$ \{ profitability, size, growth opportunity, asset tangibility, non-debt tax shield, volatility and liquidity

Since the amount of debt differs in a period of time, leverage is figured out in different manners, according to short term, long term and total debt amount. This paper focuses on determinants of listed UK firms' capital structure. The sample of this empirical study is chosen taking into account several reasons. Private UK companies are not listed on London Stock Exchange (LSE) and it is quite hard to access their financial statements. Also, accessing the financial statements of companies from outside of UK would be highly costly and time consuming. These reasons led to investigation of publicly listed UK companies.

This empirical study is based on the cross-section data from 2002 to 2009. This time horizon is carefully selected to examine the up to date determinants of capital structure and extension of past empirical studies in 2000s.

\subsection{Data}

Past empirical studies which investigating significant relationship between leverage and determinants based on mostly quantitative data from financial materials. To collect data, 
there are various ready to use sources providing primary and secondary data. Sample of this study is comprised of 202 listed UK companies.

\subsubsection{Secondary Data}

These types of data are most widely used for empirical studies of capital structure. For this study, various databases have been used to access secondary data in journals, such as Social Science Research Network (SSRN), IDEAS, Emerald and Business Source Premier.

Quantitative data which is the main source of this study is required investigating the relationships in significant level will be collected from financial databases, such as DataStream, Fame and Thomson ONE Banker. To observe these financial figures from each and single of those listed UK companies on LSE would require much time and work. Hence using financial databases would save time for investigation of data and making comments on results. In addition to this, financial databases would help this study for producing more accurate and reliable results.

\subsubsection{Data Collection}

For the purpose of this paper, the data is collected from secondary sources and researcher intends to use quantitative data and solely based on these data from DataStream. The financial information of listed UK companies will be analyzed on SPSS to examine whether there is significant correlation between leverage and its determinants.

\subsubsection{Data Sample}

Publicly listed companies available from DataStream will generate a sample. Companies that have missing financial information for any period of time within 2002-2009 will be eliminated. Also the companies in the financial sector, such as banks, financial institutions and insurance companies will not be included in the sample, since they are subject to characteristic rules and they have different structure of balance sheets from non-financial companies. The data sample includes 202 companies which is listed in appendices, is chosen from FTSE 250, since it provides wide range of companies from numerous sectors. As a result, the financial information of 202 companies in the period of 2002-2009 will form the final sample. 


\subsection{Data Analysis}

\subsubsection{Dependent Variable}

In this paper, leverage is the dependent variable. Different measures of leverage are used in past papers and each leverage measure is defined in different way. In general, two most common proxies of leverage exist such as calculated at book value of equity and at market value of equity (Lööf, 2004).

In the light of past researches (Bennett and Donnelly (1993), Rajan and Zingales (1995), Ozkan (2001), Lööf (2004), Gaud et al. (2005) and Ramlall (2009)), as mentioned in literature review, six different leverage ratios are investigated, according to total debt, short-term debt and long-term debt at both book value and market value.

Total Debt Ratio at Book Value $(\mathrm{TDBV})=$ Total Debt $($ Short-term + Long-term $) /$ Total Assets

Long-time Debt Ratio at Book Value $(\mathrm{LDBV})=$ Long-term Debt / Total Assets

Short-term Debt Ratio at Book Value $(\mathrm{SDBV})=$ Short-term Debt $/$ Total Assets

Total Debt Ratio at Market Value $($ TDMV) $=$ Total Debt / (Market Value + Total Debt $)$ Long-time Debt Ratio at Market Value $($ LDMV) = Long-term Debt / (Market Value + Total Debt)

Short-term Debt Ratio at Market Value $($ SDMV) $=$ Short-term Debt / (Market Value + Total Debt)

\subsubsection{Independent Variables}

In this paper, profitability, size, growth, tangibility, non-debt tax shield, volatility and liquidity are suggested as independent variables. Proxies, as mentioned in literature review in details, are proposed for each of these independent variables.

\subsubsection{Model Specification}

In order to investigate relationship between leverage and independent variables, the model that was used by Titman and Wessels (1988), Rajan, Zingales (1995) and Bevan and Danbolt (2004) is used with a few adjustments as mentioned in Model C. Therefore the data from DataStream would be analysed based on following empirical model. 
Leverage $=\alpha+\sum \beta_{y} D_{y}+\beta_{1} P+\beta_{2} S+\beta_{3} G+\beta_{4} T+\beta_{5}$ NDTS $+\beta_{6} \mathrm{~V}+\beta_{7} \mathrm{~L}$

$\alpha$ : Constant

$\beta$ : Regression coefficient

$D_{y}$ : Dummy variable representing year categorization

P: Profitability

S: Size
G: Growth Opportunity

T: Asset Tangibility

NDTS: Non-debt Tax Shield

V: Volatility

L: Liquidity

Following the methods from past empirical studies, pooled ordinary least squares (OLS) method is used for estimating the correlation coefficients of independent variables.

\section{Model A:}

In this model the relationships between capital structure and firm-level determinants of capital structure have been analysed in line with the empirical model stated above. The data are examined annually for the period of 2002-2009 by using SPSS. When analysed, three different leverage ratios would be used such as, total debt ratio at book value (TDBV), long-time debt ratio at book value (LDBV) and short-term debt ratio at book value (SDBV).

\section{Model B:}

Model B is replication of Model A with the adjustment of gearing proxies. The data set are analysed annually for the same period. The gearing proxies are calculated at market value instead of book value. Total debt ratio at market value (TDMV), long-time debt ratio at market value (LDBV) and short-term debt ratio at market value (SDMV) are used as dependant variables for regression analyses.

\section{Model C:}

Model C is replication of Bevan and Danbolt (2004) and Bennett and Donnelly (1993) with some adjustments. These adjustments are including the data for both independent variable and dependent variables are averaged to isolate distortions as a result of shortterm variations and to reduce possible reverse causality between the independent and dependant variables. As an application of Bevan and Danbolt (2004) and Bennett and Donnelly (1993), all gearing ratios (TDBV, LDBV, LDBV, TDMV, LDMV, SDMV) calculated as an average from year 2004 to 2007 inclusively. Profitability is calculated 
over period of the last 3 years from 2007 to 2009. Size is measured and averaged over the period 2002 to 2004. Growth is averaged for the last 3 years of data period from 2007 to 2009. Tangibility is obtained from the middle 4 years of period, 2004 to 2007. Non-debt tax shield (NDTS) is measured also over the periods of 4 years. Volatility is calculated as an average over the 8-year period from 2002 to 2009. Liquidity is also averaged for the whole period of data.

\section{Model D:}

Model D combines Model A and Model B with a few adjustments. In this model, the data from 2002 to 2009 are pooled together and time dummy variables are added, while Model A and Model B excluded the time dummy variables. Year 2002 is taken into consideration as a baseline (reference category) and seven time dummies for years from 2003 to 2009 are added to independent variables. The rationale behind adding timedummy variables is that they are control variables which capture the influence of the macroeconomics environment on leverage. In other words, adding time dummies to regression model allows capturing unobservable time specific factors on the macroeconomic level such as, interest rate, level of corporate taxation, economic situation and money supply (Lööf, 2004).

The leverage proxies are calculated at both market value and book value. Total debt ratio at book value (TDBV), long-time debt ratio at book value (LDBV) and short-term debt ratio at book value (SDBV), total debt ratio at market value (TDMV), long-time debt ratio at market value (LDBV) and short-term debt ratio at market value (SDMV) are taken as dependant variables for Model D. 


\section{Results}

This chapter presents the results obtained from analysing Model A, Model B, Model C and Model D. The analysis of variance (ANOVA) of models investigated in line with significant level of 0.05 . In the tables, the adjusted $\mathrm{R}^{2}$ shows degree of variation in leverage ratio. Gajurel (2005) suggests that it is better to take adjusted $\mathrm{R}^{2}$ rather than $\mathrm{R}^{2}$ figure into account, since $\mathrm{R}^{2}$ is more likely to produce positive results of the regressions. Adjusted $\mathrm{R}^{2}$ figures vary between $3 \%-25 \%$ in model A, 3\% - 38\% in Model B, 2\% $43 \%$ in Model C and 7\% - 34\% in Model D.

\subsection{Preliminary Analysis}

Multiple regression analysis is done in SPSS to test hypotheses. Before doing regression analysis, several descriptive statistics and multicollinearity are executed. For multicollinearity problem, bivariate correlations between the independent variables are investigated. To analyse pair-wise correlation, a data set which has 202 firms in 2002 is used.

Table 3:

Pair-wise Correlations

\begin{tabular}{|c|c|c|c|c|c|c|c|c|}
\hline Variables & $X_{1}$ & $X_{2}$ & $X_{3}$ & $\mathrm{X}_{4}$ & $X_{5}$ & $X_{6}$ & $X_{7}$ & $\mathrm{X}_{8}$ \\
\hline Gearing $\left(X_{1}\right)$ & 1.000 & & & & & & & \\
\hline Profitability $\left(\mathrm{X}_{2}\right)$ & -.110 & 1.000 & & & & & & \\
\hline Size $\left(X_{3}\right)$ & .206 & -.185 & 1.000 & & & & & \\
\hline Growth $\left(X_{4}\right)$ & -.049 & .277 & -.083 & 1.000 & & & & \\
\hline Tangibility $\left(X_{5}\right)$ & .328 & .091 & .113 & .011 & 1.000 & & & \\
\hline $\begin{array}{c}\text { Non-debt Tax Shield } \\
\left(\mathrm{X}_{6}\right)\end{array}$ & .061 & .373 & .009 & -.004 & .504 & 1.000 & & \\
\hline Volatility $\left(X_{7}\right)$ & -.107 & .219 & -.310 & .149 & -.156 & .056 & 1.000 & \\
\hline Liquidity $\left(\mathrm{X}_{8}\right)$ & -.400 & -.068 & -.376 & -.117 & -.294 & -.196 & .157 & 1.000 \\
\hline
\end{tabular}

According to Lewis-Beck (1993), the pair-wise correlations must be smaller than 0.8 not to face multicollinearity problem in multiple regression analysis. As seen in Table 2, there is no coefficient of pair-wise correlation larger than 0.8. Also it is possible to make some noticeable comments according to pair-wise correlations matrix. In line with the life-cycle theory, there is negative correlation between the growth rate and size of a 
firm. As shown in Table 2, the coefficient of growth and size pair-wise correlation is, 0.083 , negative. Besides, profitability and size of a firm are negatively correlated, as expected. 
Table 4:Descriptive

Statistics

\begin{tabular}{|c|c|c|c|c|c|c|c|c|c|}
\hline & 2002 & 2003 & 2004 & 2005 & 2006 & 2007 & 2008 & 2009 & 2002-09 \\
\hline \multicolumn{10}{|l|}{ Total Assets } \\
\hline Mean & 4936.69 & 5071.51 & 5092.16 & 5749.55 & 6496.15 & 6836.80 & 8501.20 & 8647.68 & 6416.47 \\
\hline Std Deviation & 16562.88 & 16606.93 & 16154.64 & 18063.07 & 19690.24 & 19030.09 & 24672.46 & 24343.39 & 19656.02 \\
\hline Minimum & 7.27 & 20.31 & 21.84 & 25.48 & 33.63 & 41.40 & 40.09 & 50.95 & 7.27 \\
\hline Maximum & 162002.00 & 162226.00 & 146164.00 & 132365.00 & 145122.00 & 134173.40 & 191103.40 & 178054.10 & 191103.40 \\
\hline \multicolumn{10}{|l|}{ Total Debt } \\
\hline Mean & 1111.78 & 1145.64 & 1065.80 & 1103.52 & 1168.54 & 1454.02 & 1974.31 & 2075.65 & 1387.41 \\
\hline Std Deviation & 2648.06 & 2622.19 & 2313.30 & 2247.51 & 2432.62 & 3217.37 & 4358.58 & 4960.37 & 3259.36 \\
\hline Minimum & .00 & .00 & .00 & .00 & .00 & .00 & .00 & .00 & .00 \\
\hline Maximum & 18440.00 & 16004.00 & 14278.00 & 14219.00 & 19296.00 & 23600.82 & 27592.05 & 39920.00 & 39920.00 \\
\hline \multicolumn{10}{|c|}{ Gearing at Book Value } \\
\hline Mean & 0.25 & 0.25 & 0.24 & 0.23 & 0.23 & 0.24 & 0.25 & 0.23 & 0.24 \\
\hline Std Deviation & 0.21 & 0.20 & 0.22 & 0.18 & 0.18 & 0.18 & 0.18 & 0.18 & 0.19 \\
\hline Minimum & 0.00 & 0.00 & 0.00 & 0.00 & 0.00 & 0.00 & 0.00 & 0.00 & 0.00 \\
\hline Maximum & 1.19 & 1.17 & 1.84 & 0.86 & 1.18 & 0.94 & 0.88 & 0.68 & 1.84 \\
\hline \multicolumn{10}{|c|}{$\begin{array}{c}\text { Gearing at Market } \\
\text { Value }\end{array}$} \\
\hline Mean & 0.21 & 0.26 & 0.21 & 0.20 & 0.18 & 0.18 & 0.22 & 0.29 & 0.22 \\
\hline Std Deviation & 0.17 & 0.20 & 0.18 & 0.16 & 0.14 & 0.15 & 0.17 & 0.23 & 0.18 \\
\hline Minimum & 0.00 & 0.00 & 0.00 & 0.00 & 0.00 & 0.00 & 0.00 & 0.00 & 0.00 \\
\hline Maximum & 0.78 & 0.88 & 0.91 & 0.67 & 0.71 & 0.72 & 0.71 & 0.97 & 0.97 \\
\hline \multicolumn{10}{|l|}{ EBITDA } \\
\hline Mean & 522.63 & 664.41 & 801.21 & 1000.00 & 945.71 & 1051.72 & 1199.75 & 1004.14 & 898.46 \\
\hline Std Deviation & 2006.78 & 2432.33 & 2706.23 & 3688.58 & 3740.48 & 3624.84 & 4194.38 & 3055.17 & 3257.10 \\
\hline Minimum & -3165.00 & -5524.00 & -80.00 & -244.00 & 11926.00 & -0.64 & -1808.10 & -641.40 & -11926.00 \\
\hline Maximum & 15970.59 & 18169.60 & 21050.19 & 31410.08 & 31092.46 & 31730.19 & 34794.42 & 22205.28 & 34794.42 \\
\hline
\end{tabular}


The descriptive statistics of the sample is presented in Table 3. This table simply proves how the study sample includes different range of companies in terms of total assets, debt and EBITDA. For instance, the study sample includes companies whose total assets are between GBP 7,270 and GBP 191 million. Furthermore, EBITDA of companies in the sample ranges from a minimum GBP -11.9 million to a maximum GBP 34.8 million. Also the data indicates that the amount of total debt ranges between zero and maximum level of GBP 39.9 million. Average total debt figure leveled off from 2002 to 2007. After 2008 it has risen sharply and even doubled with the effect of global financial crisis. As seen in the Table 3, gearing ratios are presented at both book value and market value and ratios calculated in terms of book value are higher than in market value. In contrast to increase in total debt, both average gearing ratios demonstrate stability for the period of $2002-2009$.

\subsection{Model A}

In this model, the dependent variables are analyzed in line with the total debt ratio at book value (TDBV), long-time debt ratio at book value (LDBV) and short-term debt ratio at book value (SDBV). Summary of a regression analysis is presented on Table 5.

Table 5: Summary of Model A

\begin{tabular}{|c|c|c|c|}
\hline Variables & TDBV & LDBV & SDBV \\
\hline Profitability & $\begin{array}{c}\text { Negative } \\
\text { Except year } 06\end{array}$ & $\begin{array}{c}\text { Negative } \\
\text { Except yr } 02\end{array}$ & $\begin{array}{c}\text { Positive } \\
\text { Except yr 02, 03, } \\
09\end{array}$ \\
\hline Size & $\begin{array}{c}\text { Positive } \\
\text { Except year } 06\end{array}$ & $\begin{array}{c}\text { Positive } \\
\text { Except year 06, } 07\end{array}$ & $\begin{array}{c}\text { Positive } \\
\text { Except yr } 04\end{array}$ \\
\hline Growth & Ambiguous & $\begin{array}{c}\text { Negative } \\
\text { Except yr 06, 07, } 08\end{array}$ & $\begin{array}{c}\text { Positive } \\
\text { Except year } 04\end{array}$ \\
\hline Tangibility & $\begin{array}{c}\text { Positive } \\
\text { Significant }\end{array}$ & $\begin{array}{c}\text { Positive } \\
\text { Significant }\end{array}$ & $\begin{array}{c}\text { Negative } \\
\text { Except year 02,09 }\end{array}$ \\
\hline NDTS & $\begin{array}{c}\text { Negative } \\
\text { Except year } 02\end{array}$ & $\begin{array}{c}\text { Negative } \\
\text { Except year 03, } 04\end{array}$ & Negative \\
\hline
\end{tabular}




\begin{tabular}{|c|c|c|c|}
\hline Volatility & Negative & Negative & $\begin{array}{c}\text { Negative } \\
\text { Significant }\end{array}$ \\
Liquidity & $\begin{array}{c}\text { Negative } \\
\text { Significant }\end{array}$ & $\begin{array}{c}\text { Negative } \\
\text { Except year 05 }\end{array}$ & $\begin{array}{c}\text { Negative } \\
\text { Significant }\end{array}$ \\
\hline
\end{tabular}

SPSS outs for per year with the figures of $F$ (ANOVA), $\mathrm{R}^{2}$, adjusted $\mathrm{R}^{2}$ and coefficients for variables are shown in Table 6. Before discussing the multiple regression analysis in the model, it is proven that regressions for total and long-term debt ratios are significant. However the regressions which short-term debt ratio is employed as an independent variable are insignificant as seen in the Table 6.

Profitability is negatively related to leverage for total debt and long-term debt ratios at book value. However, this correlation is ambiguous when short-term debt ratio is run, since it has six years positive relation and three years negative relation. Size has positive relationships for all three types of debt ratios but none of them significant. The results for growth are all different for each debt ratio measure and this conflict makes harder to interpret results. Therefore, Model B and Model C results are further investigated for this variable. There is significantly positive relationships between tangibility and total and long-term leverage, while the results for short-term leverage failed to show this relationship. According to Table 5, non-debt tax shield is negatively related to leverage, while there are several years with positive signs. The coefficient of volatility has negative sign in for all three types of leverage and it is significant for short-term leverage. There is a negative relationship between liquidity and gearing ratios and this relationship is significant for total and short-term gearing. 
Table 6: Regression results of Model A for total debt ratio (TDBV), long-term debt ratio (LDBV) and short-term debt ratio (SDBV) at book value.

Total Debt Book Value

\begin{tabular}{|c|c|c|c|c|c|c|c|c|c|c|c|c|c|c|c|c|c|c|c|c|c|c|c|c|}
\hline & \multicolumn{3}{|c|}{2002} & \multicolumn{3}{|c|}{2003} & \multicolumn{3}{|c|}{2004} & \multicolumn{3}{|c|}{2005} & \multicolumn{3}{|c|}{2006} & \multicolumn{3}{|c|}{2007} & \multicolumn{3}{|c|}{2008} & \multicolumn{3}{|c|}{2009} \\
\hline $\mathbf{F}$ & \multicolumn{3}{|c|}{7.38} & \multicolumn{3}{|c|}{7.47} & \multicolumn{3}{|c|}{7.29} & \multicolumn{3}{|c|}{6.23} & \multicolumn{3}{|c|}{5.75} & \multicolumn{3}{|c|}{9.76} & \multicolumn{3}{|c|}{8.15} & \multicolumn{3}{|c|}{8.08} \\
\hline $\mathbf{R 2}$ & \multicolumn{3}{|c|}{0.24} & \multicolumn{3}{|c|}{0.24} & \multicolumn{3}{|c|}{0.23} & \multicolumn{3}{|c|}{0.20} & \multicolumn{3}{|c|}{0.18} & \multicolumn{3}{|c|}{0.27} & \multicolumn{3}{|c|}{0.24} & \multicolumn{3}{|c|}{0.24} \\
\hline Adj R2 & \multicolumn{3}{|c|}{0.21} & \multicolumn{3}{|c|}{0.21} & \multicolumn{3}{|c|}{0.20} & \multicolumn{3}{|c|}{0.17} & \multicolumn{3}{|c|}{0.15} & \multicolumn{3}{|c|}{0.25} & & 0.21 & & & 0.21 & \\
\hline Sign. & & 0.00 & & & 0.00 & & & 0.00 & & & 0.00 & & & 0.00 & & & 0.00 & & & 0.00 & & & 0.00 & \\
\hline & Beta & $\mathbf{t}$ & Sig & Beta & $t$ & Sig & Beta & $t$ & Sig & Beta & $t$ & Sig & Beta & $t$ & Sig & Beta & $t$ & Sig & Beta & $t$ & Sig & Beta & $t$ & Sig \\
\hline Const. & 0.13 & 0.97 & 0.33 & 0.07 & 0.57 & 0.57 & 0.08 & 0.65 & 0.52 & 0.00 & 0.03 & 0.97 & 0.30 & 2.42 & 0.02 & 0.26 & 2.22 & 0.03 & 0.21 & 1.65 & 0.10 & 0.20 & 1.56 & 0.12 \\
\hline Prof. & -0.11 & -1.49 & 0.14 & 0.00 & 0.00 & 1.00 & -0.15 & -1.94 & 0.05 & -0.15 & -2.00 & 0.05 & 0.01 & 0.15 & 0.88 & -0.06 & -0.79 & 0.43 & -0.26 & -3.36 & 0.00 & -0.11 & -1.57 & 0.12 \\
\hline Size & 0.10 & 1.21 & 0.23 & 0.14 & 1.77 & 0.08 & 0.14 & 1.84 & 0.07 & 0.15 & 2.03 & 0.04 & -0.02 & -0.31 & 0.75 & 0.02 & 0.22 & 0.82 & 0.05 & 0.64 & 0.52 & 0.06 & 0.83 & 0.41 \\
\hline Growth & -0.30 & -4.36 & 0.00 & -0.21 & -3.01 & 0.00 & -0.05 & -0.68 & 0.50 & 0.01 & 0.09 & 0.93 & 0.04 & 0.51 & 0.61 & 0.09 & 1.25 & 0.21 & 0.12 & 1.71 & 0.09 & -0.10 & -1.48 & 0.14 \\
\hline Tangib. & 0.17 & 2.14 & 0.03 & 0.21 & 2.54 & 0.01 & 0.26 & 3.29 & 0.00 & 0.32 & 3.91 & 0.00 & 0.31 & 3.71 & 0.00 & 0.38 & 4.99 & 0.00 & 0.36 & 4.48 & 0.00 & 0.36 & 4.58 & 0.00 \\
\hline NDTS & -0.03 & -0.41 & 0.68 & 0.01 & 0.08 & 0.94 & -0.03 & -0.40 & 0.69 & -0.02 & -0.25 & 0.80 & -0.14 & -1.68 & 0.09 & -0.19 & -2.43 & 0.02 & -0.11 & -1.30 & 0.20 & -0.13 & -1.56 & 0.12 \\
\hline Liquid. & -0.20 & -2.49 & 0.01 & -0.21 & -2.71 & 0.01 & -0.16 & -2.01 & 0.05 & -0.05 & -0.64 & 0.53 & -0.23 & -3.08 & 0.00 & -0.27 & -3.64 & 0.00 & -0.17 & -2.29 & 0.02 & -0.24 & -3.34 & 0.00 \\
\hline
\end{tabular}

Long-Term Book Value

\begin{tabular}{|c|c|c|c|c|c|c|c|c|}
\hline & 2002 & 2003 & 2004 & 2005 & 2006 & 2007 & 2008 & 2009 \\
\hline $\mathbf{F}$ & 6.21 & 6.93 & 7.79 & 5.64 & 4.82 & 9.19 & 7.88 & 6.86 \\
\hline R2 & 0.21 & 0.22 & 0.24 & 0.19 & 0.16 & 0.26 & 0.23 & 0.21 \\
\hline Adj R2 & 0.18 & 0.19 & 0.21 & 0.16 & 0.12 & 0.23 & 0.20 & 0.18 \\
\hline Sign. & 0.00 & 0.00 & 0.00 & 0.00 & 0.00 & 0.00 & 0.00 & 0.00 \\
\hline
\end{tabular}




\begin{tabular}{|c|c|c|c|c|c|c|c|c|c|c|c|c|c|c|c|c|c|c|c|c|c|c|c|c|}
\hline & Beta & $\mathbf{t}$ & $\mathbf{S i g}$ & Beta & $\mathbf{t}$ & $\mathbf{S i g}$ & Beta & $\mathbf{t}$ & $\mathbf{S i g}$ & Beta & $\mathbf{t}$ & $\mathbf{S i g}$ & Beta & $\mathbf{t}$ & $\mathbf{S i g}$ & Beta & $\mathbf{t}$ & Sig & Beta & $\mathbf{t}$ & Sig & Beta & $\mathbf{t}$ & Sig \\
\hline Const. & 0.08 & 0.58 & 0.56 & 0.01 & 0.07 & 0.94 & -0.02 & -0.15 & 0.88 & -0.02 & -0.15 & 0.88 & -0.25 & 2.02 & 0.04 & 0.24 & 2.15 & 0.03 & 0.17 & 1.40 & 0.16 & 0.14 & 1.12 & 0.26 \\
\hline Prof. & -0.11 & -1.45 & 0.15 & 0.01 & 0.10 & 0.92 & -0.20 & -2.66 & 0.01 & -0.16 & -2.07 & 0.04 & -0.03 & -0.34 & 0.73 & -0.14 & -1.79 & 0.07 & -0.28 & -3.65 & 0.00 & -0.09 & -1.23 & 0.22 \\
\hline Size & 0.10 & 1.15 & 0.25 & 0.13 & 1.65 & 0.10 & 0.16 & 2.16 & 0.03 & 0.14 & 1.76 & 0.08 & -0.03 & -0.47 & 0.64 & -0.01 & -0.22 & 0.83 & 0.03 & 0.45 & 0.66 & 0.06 & 0.83 & 0.41 \\
\hline Growth & -0.33 & -4.71 & 0.00 & -0.24 & -3.48 & 0.00 & -0.02 & -0.29 & 0.77 & -0.01 & -0.14 & 0.89 & 0.02 & 0.33 & 0.74 & 0.08 & 1.13 & 0.26 & 0.12 & 1.75 & 0.08 & -0.11 & -1.71 & 0.09 \\
\hline Tangib. & 0.16 & 1.92 & 0.06 & 0.25 & 3.04 & 0.00 & 0.33 & 4.10 & 0.00 & 0.35 & 4.20 & 0.00 & 0.36 & 4.24 & 0.00 & 0.43 & 5.55 & 0.00 & 0.40 & 4.88 & 0.00 & 0.37 & 4.60 & 0.00 \\
\hline NDTS & -0.03 & -0.41 & 0.68 & 0.03 & 0.33 & 0.74 & 0.00 & -0.04 & 0.97 & -0.02 & -0.23 & 0.82 & -0.13 & -1.52 & 0.13 & -0.14 & -1.69 & 0.09 & -0.10 & -1.19 & 0.24 & -0.11 & -1.27 & 0.20 \\
\hline Volat. & -0.04 & -0.47 & 0.64 & -0.11 & -1.37 & 0.17 & -0.12 & -1.46 & 0.15 & -0.09 & -1.24 & 0.22 & -0.12 & -1.67 & 0.10 & -0.12 & -1.72 & 0.09 & -0.10 & -1.47 & 0.14 & -0.09 & -1.27 & 0.21 \\
\hline Liquid. & -0.13 & -1.61 & 0.11 & -0.12 & -1.50 & 0.14 & -0.06 & -0.73 & 0.47 & 0.01 & 0.11 & 0.91 & -0.14 & -1.81 & 0.07 & -0.18 & -2.44 & 0.02 & -0.10 & -1.31 & 0.19 & -0.18 & -2.47 & 0.01 \\
\hline
\end{tabular}

\section{Short-Term Book}

\section{Value}

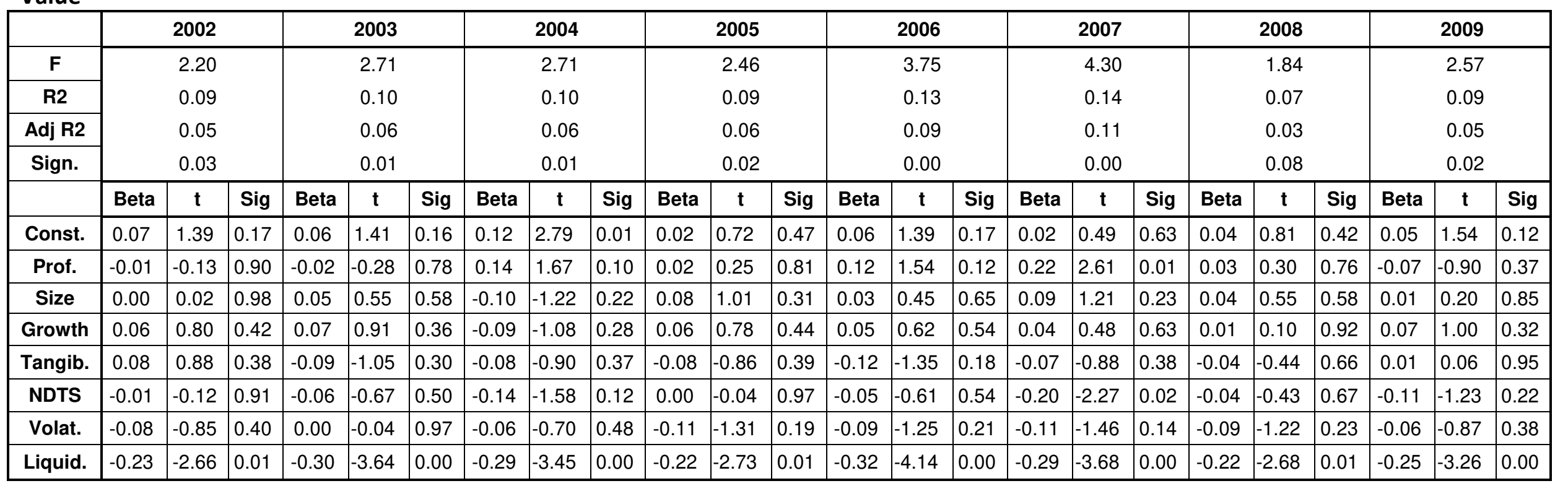




\subsection{Model B}

In Model B, the dependent variables are investigated with significance level of 0.05 for the total debt ratio at market value (TDMV), long-time debt ratio at market value (LDMV) and short-term debt ratio at market value (SDMV). Observations, derived from Model B, are presented on Table 7. The more detailed yearly results with the statistics are illustrated in Table 8 and as seen, the regressions for total and long-term gearing are significant. Likewise in Model A, the regressions for short-term gearing are insignificant.

Table 7: Summary of Model B

\begin{tabular}{|c|c|c|c|}
\hline Variables & TDMV & LDMV & SDMV \\
\hline Profitability & $\begin{array}{c}\text { Negative } \\
\text { Significant }\end{array}$ & $\begin{array}{c}\text { Negative } \\
\text { Significant }\end{array}$ & $\begin{array}{c}\text { Negative } \\
\text { Except year } 07\end{array}$ \\
\hline Size & Positive & Positive & $\begin{array}{c}\text { Positive } \\
\text { Except year } 02,04\end{array}$ \\
\hline Growth & Negative & Negative & $\begin{array}{c}\text { Negative } \\
\text { Except year } 03\end{array}$ \\
\hline Tangibility & Positive & $\begin{array}{l}\text { Positive } \\
\text { Significant }\end{array}$ & $\begin{array}{c}\text { Negative } \\
\text { Except year 02, } 04\end{array}$ \\
\hline NDTS & Negative & $\begin{array}{c}\text { Negative } \\
\text { Except year } 04\end{array}$ & $\begin{array}{c}\text { Negative } \\
\text { Except year } 03\end{array}$ \\
\hline Volatility & Negative & Negative & $\begin{array}{c}\text { Negative } \\
\text { Except year } 03\end{array}$ \\
\hline Liquidity & Negative & $\begin{array}{c}\text { Negative } \\
\text { Except year } 05\end{array}$ & $\begin{array}{c}\text { Negative } \\
\text { Significant }\end{array}$ \\
\hline
\end{tabular}

The regression coefficients of profitability are negative and significant for total and long-term leverage. As in Model A, company size positively related to gearing. Contrary to Model A, all forms of leverages are inversely related to companies' growth rates. Also it is found that long-term gearing has positive and significant relationship with asset structure (tangibility). Similarly Model A, non-debt tax shield and volatility are negatively related to all type of gearing measures. As clearly seen in Table 7, liquidity has inverse relationship with all form of leverage and this relationship is significant for short-term leverage. 
Table 8: Regression results of Model B for total debt ratio (TDMV), long-term debt ratio (LDMV) and short-term debt ratio (SDMV) at market value.

Total Debt Market Value

\begin{tabular}{|c|c|c|c|c|c|c|c|c|c|c|c|c|c|c|c|c|c|c|c|c|c|c|c|c|}
\hline & \multicolumn{3}{|c|}{2002} & \multicolumn{3}{|c|}{2003} & \multicolumn{3}{|c|}{2004} & \multicolumn{3}{|c|}{2005} & \multicolumn{3}{|c|}{2006} & \multicolumn{3}{|c|}{2007} & \multicolumn{3}{|c|}{2008} & \multicolumn{3}{|c|}{2009} \\
\hline$F$ & \multicolumn{3}{|c|}{8.72} & \multicolumn{3}{|c|}{10.9} & \multicolumn{3}{|c|}{15.4} & \multicolumn{3}{|c|}{15.0} & \multicolumn{3}{|c|}{17.8} & \multicolumn{3}{|c|}{15.9} & \multicolumn{3}{|c|}{16.7} & \multicolumn{3}{|c|}{16.3} \\
\hline R2 & \multicolumn{3}{|c|}{0.27} & \multicolumn{3}{|c|}{0.31} & \multicolumn{3}{|c|}{0.39} & \multicolumn{3}{|c|}{0.38} & \multicolumn{3}{|c|}{0.41} & \multicolumn{3}{|c|}{0.38} & \multicolumn{3}{|c|}{0.39} & \multicolumn{3}{|c|}{0.38} \\
\hline Adj R2 & \multirow{2}{*}{\multicolumn{3}{|c|}{$\begin{array}{l}0.24 \\
0.00\end{array}$}} & \multirow{2}{*}{\multicolumn{3}{|c|}{$\begin{array}{l}0.28 \\
0.00\end{array}$}} & \multirow{2}{*}{\multicolumn{3}{|c|}{$\begin{array}{l}0.37 \\
0.00\end{array}$}} & \multirow{2}{*}{\multicolumn{3}{|c|}{$\begin{array}{l}0.35 \\
0.00\end{array}$}} & \multirow{2}{*}{\multicolumn{3}{|c|}{$\begin{array}{l}0.38 \\
0.00\end{array}$}} & \multirow{2}{*}{\multicolumn{3}{|c|}{$\begin{array}{l}0.36 \\
0.00\end{array}$}} & & 0.37 & & & 0.36 & \\
\hline Sign. & & & & & & & & & & & & & & & & & & & & 0.00 & & & 0.00 & \\
\hline & Beta & $\mathbf{t}$ & Sig & Beta & $\mathbf{t}$ & Sig & Beta & $t$ & Sig & Beta & $t$ & Sig & Beta & $\mathbf{t}$ & Sig & Beta & $\mathbf{t}$ & Sig & Beta & $t$ & Sig & Beta & $t$ & Sig \\
\hline Const. & 0.21 & 1.63 & 0.11 & 0.11 & 0.83 & 0.41 & 0.08 & 0.69 & 0.49 & -0.04 & -0.42 & 0.68 & 0.09 & 1.03 & 0.30 & 0.11 & 1.19 & 0.23 & 0.16 & 1.44 & 0.15 & 0.17 & 1.13 & 0.26 \\
\hline Prof. & -0.13 & -1.83 & 0.07 & -0.35 & -5.37 & 0.00 & -0.38 & -5.60 & 0.00 & -0.31 & -4.76 & 0.00 & -0.30 & -4.56 & 0.00 & -0.28 & -3.87 & 0.00 & -0.42 & -6.20 & 0.00 & -0.44 & -6.74 & 0.00 \\
\hline Size & 0.01 & 0.13 & 0.90 & 0.12 & 1.60 & 0.11 & 0.15 & 2.18 & 0.03 & 0.21 & 3.20 & 0.00 & 0.11 & 1.85 & 0.07 & 0.09 & 1.48 & 0.14 & 0.10 & 1.59 & 0.11 & 0.12 & 1.95 & 0.05 \\
\hline Growth & -0.17 & -2.59 & 0.01 & -0.05 & -0.77 & 0.44 & -0.06 & -0.93 & 0.35 & -0.13 & -1.91 & 0.06 & -0.02 & -0.40 & 0.69 & -0.01 & -0.09 & 0.93 & -0.06 & -1.04 & 0.30 & -0.13 & -2.16 & 0.03 \\
\hline Tangib. & 0.37 & 4.69 & 0.00 & 0.33 & 4.22 & 0.00 & 0.36 & 5.01 & 0.00 & 0.39 & 5.43 & 0.00 & 0.50 & 7.03 & 0.00 & 0.47 & 6.59 & 0.00 & 0.35 & 4.87 & 0.00 & 0.29 & 4.07 & 0.00 \\
\hline NDTS & -0.10 & -1.22 & 0.23 & -0.02 & -0.30 & 0.77 & -0.01 & -0.13 & 0.90 & -0.05 & -0.73 & 0.47 & -0.19 & -2.59 & 0.01 & -0.20 & -2.66 & 0.01 & -0.07 & -0.92 & 0.36 & -0.03 & -0.43 & 0.67 \\
\hline Volat. & -0.23 & -2.83 & 0.01 & -0.11 & -1.38 & 0.17 & -0.10 & -1.36 & 0.18 & -0.08 & -1.27 & 0.21 & -0.14 & -2.24 & 0.03 & -0.10 & -1.55 & 0.12 & -0.10 & -1.58 & 0.11 & -0.06 & -1.00 & 0.32 \\
\hline Liquid. & -0.11 & -1.39 & 0.17 & -0.13 & -1.78 & 0.08 & -0.11 & -1.55 & 0.12 & -0.04 & -0.60 & 0.55 & -0.12 & -1.83 & 0.07 & -0.13 & -1.97 & 0.05 & -0.18 & -2.78 & 0.01 & -0.18 & -2.82 & 0.01 \\
\hline
\end{tabular}

Long-term Debt Market Value

\begin{tabular}{|c|c|c|c|c|c|c|c|c|}
\hline & 2002 & 2003 & 2004 & 2005 & 2006 & 2007 & 2008 & 2009 \\
\hline$F$ & 7.71 & 9.42 & 14.4 & 13.3 & 14.8 & 15.9 & 14.2 & 13.5 \\
\hline $\mathbf{R 2}$ & 0.25 & 0.28 & 0.37 & 0.35 & 0.36 & 0.38 & 0.36 & 0.34 \\
\hline Adj R2 & 0.22 & 0.25 & 0.35 & 0.33 & 0.34 & 0.36 & 0.33 & 0.32 \\
\hline Sign. & 0.00 & 0.00 & 0.00 & 0.00 & 0.00 & 0.00 & 0.00 & 0.00 \\
\hline
\end{tabular}




\begin{tabular}{|c|c|c|c|c|c|c|c|c|c|c|c|c|c|c|c|c|c|c|c|c|c|c|c|c|}
\hline & Beta & $t$ & Sig & Beta & $\mathbf{t}$ & Sig & Beta & $t$ & Sig & Beta & $\mathbf{t}$ & Sig & Beta & $\mathbf{t}$ & Sig & Beta & $\mathbf{t}$ & Sig & Beta & $\mathbf{t}$ & Sig & Beta & $t$ & Sig \\
\hline Const. & 0.12 & 1.00 & 0.32 & 0.02 & 0.15 & 0.88 & 0.02 & 0.18 & 0.86 & -0.06 & -0.54 & 0.59 & 0.08 & 0.97 & 0.33 & 0.11 & 1.35 & 0.18 & 0.17 & 1.56 & 0.12 & 0.14 & 0.92 & 0.36 \\
\hline Prof. & -0.12 & -1.69 & 0.09 & -0.27 & -4.09 & 0.00 & -0.38 & -5.47 & 0.00 & -0.31 & -4.58 & 0.00 & -0.28 & -4.18 & 0.00 & -0.34 & -4.71 & 0.00 & -0.41 & -5.89 & 0.00 & -0.40 & -5.95 & 0.00 \\
\hline Size & 0.03 & 0.42 & 0.67 & 0.13 & 1.63 & 0.10 & 0.15 & 2.18 & 0.03 & 0.19 & 2.72 & 0.01 & 0.08 & 1.19 & 0.23 & 0.07 & 1.17 & 0.24 & 0.06 & 0.90 & 0.37 & 0.11 & 1.66 & 0.10 \\
\hline Growth & -0.19 & -2.81 & 0.01 & -0.09 & -1.41 & 0.16 & -0.05 & -0.72 & 0.48 & -0.11 & -1.70 & 0.09 & -0.02 & -0.33 & 0.74 & -0.01 & -0.19 & 0.85 & -0.05 & -0.74 & .46 & 0.13 & -2.19 & .03 \\
\hline Tangib. & 0.38 & 4.69 & 0.00 & 0.38 & 4.81 & 0.00 & 0.39 & 5.34 & 0.00 & 0.43 & 5.82 & 0.00 & 0.53 & 7.29 & 0.00 & 0.46 & 6.40 & 0.00 & 0.39 & 5.24 & 0.00 & 0.32 & 4.39 & 0.00 \\
\hline NDTS & -0.10 & -1.27 & 0.21 & -0.02 & -0.23 & 0.82 & 0.01 & 0.09 & 0.93 & -0.05 & -0.65 & 0.52 & -0.18 & -2.42 & 0.02 & -0.11 & -1.48 & 0.14 & -0.08 & -1.07 & 0.29 & -0.03 & -0.43 & 0.67 \\
\hline Volat. & -0.22 & -2.60 & 0.01 & -0.13 & -1.62 & 0.11 & -0.09 & -1.31 & 0.19 & -0.06 & -0.95 & 0.34 & -0.11 & -1.76 & 0.08 & -0.08 & -1.33 & 0.18 & -0.07 & -1.17 & 0.24 & -0.05 & -0.82 & 0.41 \\
\hline Liquid. & -0.04 & -0.47 & 0.64 & -0.04 & -0.52 & 0.60 & -0.04 & -0.61 & 0.54 & 0.02 & 0.25 & 0.80 & -0.06 & -0.83 & 0.41 & -0.09 & -1.31 & 0.19 & -0.14 & -2.05 & 0.04 & -0.13 & -2.03 & 0.04 \\
\hline
\end{tabular}

Short-term Debt Market Value

\begin{tabular}{|c|c|c|c|c|c|c|c|c|c|c|c|c|c|c|c|c|c|c|c|c|c|c|c|c|}
\hline & \multicolumn{3}{|c|}{2002} & \multicolumn{3}{|c|}{2003} & \multicolumn{3}{|c|}{2004} & \multicolumn{3}{|c|}{2005} & \multicolumn{3}{|c|}{2006} & \multicolumn{3}{|c|}{2007} & \multicolumn{3}{|c|}{2008} & \multicolumn{3}{|c|}{2009} \\
\hline$F$ & \multirow{2}{*}{\multicolumn{3}{|c|}{$\begin{array}{l}1.69 \\
0.07\end{array}$}} & \multirow{2}{*}{\multicolumn{3}{|c|}{$\begin{array}{l}4.97 \\
0.17\end{array}$}} & \multirow{2}{*}{\multicolumn{3}{|c|}{$\begin{array}{l}2.36 \\
0.09\end{array}$}} & \multirow{2}{*}{\multicolumn{3}{|c|}{3.00}} & \multirow{2}{*}{\multicolumn{3}{|c|}{$\begin{array}{l}4.88 \\
016\end{array}$}} & \multirow{2}{*}{\multicolumn{3}{|c|}{$\begin{array}{l}4.92 \\
0.16\end{array}$}} & \multicolumn{3}{|c|}{2.89} & \multicolumn{3}{|c|}{4.57} \\
\hline R2 & & & & & & & & & & & & & & & & & & & & 0.10 & & & 0.15 & \\
\hline Adj R2 & \multicolumn{3}{|c|}{0.03} & \multicolumn{3}{|c|}{0.14} & \multirow{2}{*}{\multicolumn{3}{|c|}{$\begin{array}{l}0.05 \\
0.03\end{array}$}} & \multirow{2}{*}{\multicolumn{3}{|c|}{$\begin{array}{l}0.07 \\
0.01\end{array}$}} & \multirow{2}{*}{\multicolumn{3}{|c|}{$\begin{array}{l}0.12 \\
0.00\end{array}$}} & \multirow{2}{*}{\multicolumn{3}{|c|}{$\begin{array}{l}0.13 \\
0.00\end{array}$}} & \multirow{2}{*}{\multicolumn{3}{|c|}{$\begin{array}{l}0.07 \\
0.01\end{array}$}} & \multirow{2}{*}{\multicolumn{3}{|c|}{$\begin{array}{l}0.12 \\
0.00\end{array}$}} \\
\hline Sign. & & 0.11 & & & 0.00 & & & & & & & & & & & & & & & & & & & \\
\hline & Beta & $t$ & Sig & Beta & $t$ & Sig & Beta & $t$ & Sig & Beta & $t$ & Sig & Beta & $t$ & Sig & Beta & $t$ & Sig & Beta & $t$ & Sig & Beta & $t$ & Sig \\
\hline Const. & 0.10 & 1.78 & 0.08 & 0.09 & 1.89 & 0.06 & 0.08 & 2.33 & 0.02 & 0.01 & 0.38 & 0.70 & 0.01 & 0.24 & 0.81 & -0.01 & -0.40 & 0.69 & -0.01 & -0.25 & 0.80 & 0.08 & 0.86 & 0.39 \\
\hline Prof. & -0.05 & $\mid-0.63$ & 0.53 & -0.31 & -4.29 & 0.00 & $\mid-0.08$ & -0.94 & 0.35 & -0.07 & $\mid-0.88$ & 0.38 & -0.11 & \begin{tabular}{|l|}
-1.38 \\
\end{tabular} & 0.17 & 0.01 & 0.08 & 0.94 & -0.10 & -1.15 & 0.25 & -0.26 & -3.44 & 0.00 \\
\hline Size & -0.06 & -0.68 & 0.50 & 0.02 & 0.22 & 0.83 & -0.03 & -0.39 & 0.69 & 0.13 & 1.66 & 0.10 & 0.15 & 2.04 & 0.04 & 0.20 & 2.71 & 0.01 & 0.15 & 1.96 & 0.05 & 0.10 & 1.33 & 0.19 \\
\hline Growth & -0.03 & \begin{tabular}{|l|}
-0.35 \\
\end{tabular} & 0.73 & 0.11 & 1.50 & 0.13 & -0.06 & -0.75 & 0.46 & \begin{tabular}{|l|}
-0.07 \\
\end{tabular} & -0.88 & 0.38 & -0.02 & -0.24 & 0.81 & -0.06 & -0.82 & 0.41 & -0.07 & -0.88 & 0.38 & 0.00 & -0.03 & 0.98 \\
\hline Tangib. & 0.09 & 1.05 & 0.29 & -0.06 & -0.76 & 0.45 & 0.02 & 0.19 & 0.85 & -0.06 & -0.72 & 0.47 & -0.03 & -0.33 & 0.74 & -0.01 & -0.18 & 0.86 & -0.07 & -0.79 & 0.43 & -0.06 & -0.77 & 0.44 \\
\hline NDTS & -0.02 & -0.23 & \begin{tabular}{|l|}
0.82 \\
\end{tabular} & -0.02 & -0.23 & 0.82 & -0.11 & -1.27 & 0.21 & -0.02 & -0.28 & 0.78 & -0.06 & -0.65 & 0.51 & -0.16 & -1.87 & 0.06 & 0.03 & 0.37 & 0.71 & -0.01 & -0.09 & 0.93 \\
\hline Volat. & -0.12 & \begin{tabular}{|l|}
-1.26 \\
\end{tabular} & 0.21 & 0.03 & 0.36 & 0.72 & -0.06 & -0.67 & 0.50 & -0.08 & -1.06 & 0.29 & -0.11 & \begin{tabular}{|l|}
-1.53 \\
\end{tabular} & 0.13 & -0.09 & -1.29 & 0.20 & -0.09 & -1.20 & 0.23 & -0.05 & -0.73 & 0.46 \\
\hline Liquid. & -0.19 & -2.14 & 0.03 & -0.29 & -3.57 & 0.00 & -0.25 & -2.95 & 0.00 & -0.21 & -2.65 & 0.01 & -0.23 & -3.03 & 0.00 & -0.24 & -2.99 & 0.00 & -0.17 & -2.11 & 0.04 & -0.24 & -3.17 & 0.00 \\
\hline
\end{tabular}




\subsection{Model C}

In model C, which is a replication of Bevan and Danbolt (2004) and Bennett and Donnelly (1993) study, the variables are averaged to reduce distortions. In line with the past researches, as mentioned in methodology, six different leverage ratios are investigated such as, total debt, short-term debt and long-term debt at both book value and market value. The summaries of results derived from Model $\mathrm{C}$ are presented in Table 9. Regression results such as $F$ (analysis of variance), $\mathrm{R}^{2}$, adjusted $\mathrm{R}^{2}$ and coefficients for variables are illustrated in more details in Table 10.

Table 9: Summary of Model C

\begin{tabular}{|c|c|c|c|c|c|c|}
\hline Variables & TDBV & LDBV & SDBV & TDMV & LDMV & SDMV \\
\hline Profitability & Negative & Negative & Positive & $\begin{array}{c}\text { Negative } \\
\text { Significant }\end{array}$ & $\begin{array}{c}\text { Negative } \\
\text { Significant }\end{array}$ & Negative \\
Size & Positive & Positive & Positive & Positive & Positive & Positive \\
Growth & Negative & Negative & Positive & Negative & Negative & Positive \\
Tangibility & Positive & Positive & Negative & Positive & Positive & Pignificant \\
Significant & Positive \\
NDTS & Negative & Negative & Negative & Negative & Negative & No Relation \\
Volatility & Positive & No Relation & Positive & Negative & Negative & Negative \\
Liquidity & $\begin{array}{c}\text { Negative } \\
\text { Significant }\end{array}$ & Negative & Negative & $\begin{array}{c}\text { Negative } \\
\text { Significant }\end{array}$ & $\begin{array}{c}\text { Negative } \\
\text { Significant }\end{array}$ & Negative \\
\hline
\end{tabular}

Profitability has inverse relationship with all form of leverage except short-term leverage at book value. Likewise Model A and Model B, size of company is positively related to leverage. Growth ratio has negative relationships with total and long-term gearings, but has positive relationships with short-term gearings. As seen in Table 9, tangibility has ambiguous relationships with all forms gearings. As expected, it is observed that nondebt tax shield and liquidity are inversely related to gearing ratios. Surprisingly, volatility is negatively related to leverages at book value and positively related to leverages at market value. 
Table 10: Regression results of Model C for total debt ratio (TDBV), long-term debt ratio (LDBV), short-term debt ratio (SDBV) at book value and total debt ratio (TDMV), long-term debt ratio (LDMV) and short-term debt ratio (SDMV) at market value.

Model C

\begin{tabular}{|c|c|c|c|c|c|c|c|c|c|c|c|c|c|c|c|c|c|c|}
\hline & \multicolumn{3}{|c|}{ TDBV } & \multicolumn{3}{|c|}{ LDBV } & \multicolumn{3}{|c|}{ SDBV } & \multicolumn{3}{|c|}{ TDMV } & \multicolumn{3}{|c|}{ LDMV } & \multicolumn{3}{|c|}{ STMV } \\
\hline$F$ & \multicolumn{3}{|c|}{8.54} & \multicolumn{3}{|c|}{8.30} & \multicolumn{3}{|c|}{1.85} & \multicolumn{3}{|c|}{21.7} & \multicolumn{3}{|c|}{18.1} & \multicolumn{3}{|c|}{1.45} \\
\hline $\mathbf{R 2}$ & \multicolumn{3}{|c|}{0.25} & \multicolumn{3}{|c|}{0.24} & \multicolumn{3}{|c|}{0.07} & \multicolumn{3}{|c|}{0.45} & \multicolumn{3}{|c|}{0.41} & \multicolumn{3}{|c|}{0.05} \\
\hline Significance & \multicolumn{3}{|c|}{0.00} & \multicolumn{3}{|c|}{$\begin{array}{l}0.21 \\
0.00\end{array}$} & \multicolumn{3}{|c|}{0.08} & \multicolumn{3}{|c|}{0.00} & \multicolumn{3}{|c|}{0.00} & \multicolumn{3}{|c|}{0.19} \\
\hline & Beta & $t$ & Sig & Beta & $t$ & Sig & Beta & $t$ & Sig & Beta & $t$ & Sig & Beta & $t$ & Sig & Beta & $t$ & $\overline{\text { Sig }}$ \\
\hline Constant & 0.28 & 2.47 & 0.01 & 0.25 & 2.26 & 0.03 & 0.06 & 1.60 & 0.11 & 0.23 & 2.57 & 0.01 & 0.21 & 2.35 & 0.02 & 0.07 & 1.26 & 0.21 \\
\hline Size & 0.03 & 0.44 & 0.66 & 0.01 & 0.16 & 0.87 & 0.02 & 0.19 & 0.85 & 0.06 & 1.03 & 0.30 & 0.04 & 0.59 & 0.55 & 0.02 & 0.20 & 0.84 \\
\hline Growth & -0.07 & -1.02 & 0.31 & -0.09 & -1.26 & 0.21 & 0.07 & 0.91 & 0.37 & -0.10 & -1.78 & 0.08 & -0.10 & -1.65 & 0.10 & 0.04 & 0.48 & 0.63 \\
\hline Tangibility & 0.30 & 3.87 & 0.00 & 0.34 & 4.40 & 0.00 & -0.03 & -0.39 & 0.70 & 0.40 & 6.05 & 0.00 & 0.41 & 5.98 & 0.00 & 0.01 & 0.11 & 0.91 \\
\hline NDTS & -0.12 & -1.52 & 0.13 & -0.11 & -1.32 & 0.19 & -0.09 & -1.00 & 0.32 & -0.07 & -0.94 & 0.35 & -0.04 & -0.61 & 0.54 & 0.00 & 0.00 & 1.00 \\
\hline Volatility & 0.04 & 0.62 & 0.54 & 0.00 & 0.02 & 0.99 & 0.13 & 1.65 & 0.10 & -0.07 & -1.10 & 0.27 & -0.04 & -0.69 & 0.49 & -0.08 & -1.07 & 0.29 \\
\hline
\end{tabular}




\subsection{Model D:}

In Model D, as a combination of Model A and Model B with time dummies, six leverage ratios (TDBV, LDBV, SDVB, TDMV, LDMV and SDMV) are calculated. Since year 2002 is taken as reference year, it is omitted from dummy variables. The table below shows a summary of the regression results with time dummies.

Table 11: Summary of Model D

\begin{tabular}{|c|c|c|c|c|c|c|}
\hline Variables & TDBV & LDBV & SDBV & TDMV & LDMV & SDMV \\
\hline Profitability & $\begin{array}{c}\text { Negative } \\
\text { Significant }\end{array}$ & $\begin{array}{c}\text { Negative } \\
\text { Significant }\end{array}$ & Positive & $\begin{array}{c}\text { Negative } \\
\text { Significant }\end{array}$ & $\begin{array}{c}\text { Negative } \\
\text { Significant }\end{array}$ & $\begin{array}{c}\text { Negative } \\
\text { Significant }\end{array}$ \\
\hline Size & Positive & Positive & Positive & $\begin{array}{c}\text { Positive } \\
\text { Significant }\end{array}$ & $\begin{array}{c}\text { Positive } \\
\text { Significant }\end{array}$ & Positive \\
\hline Growth & $\begin{array}{l}\text { Negative } \\
\text { Significant }\end{array}$ & $\begin{array}{l}\text { Negative } \\
\text { Significant }\end{array}$ & Positive & $\begin{array}{l}\text { Negative } \\
\text { Significant }\end{array}$ & $\begin{array}{l}\text { Negative } \\
\text { Significant }\end{array}$ & Negative \\
\hline Tangibility & $\begin{array}{c}\text { Positive } \\
\text { Significant }\end{array}$ & $\begin{array}{c}\text { Positive } \\
\text { Significant }\end{array}$ & Negative & $\begin{array}{c}\text { Positive } \\
\text { Significant }\end{array}$ & $\begin{array}{c}\text { Positive } \\
\text { Significant }\end{array}$ & Negative \\
\hline NDTS & Negative & Negative & Negative & $\begin{array}{l}\text { Negative } \\
\text { Significant }\end{array}$ & $\begin{array}{l}\text { Negative } \\
\text { Significant }\end{array}$ & Negative \\
\hline Volatility & $\begin{array}{l}\text { Negative } \\
\text { Significant }\end{array}$ & $\begin{array}{l}\text { Negative } \\
\text { Significant }\end{array}$ & Negative & $\begin{array}{l}\text { Negative } \\
\text { Significant }\end{array}$ & $\begin{array}{l}\text { Negative } \\
\text { Significant }\end{array}$ & Negative \\
\hline Liquidity & $\begin{array}{l}\text { Negative } \\
\text { Significant }\end{array}$ & $\begin{array}{l}\text { Negative } \\
\text { Significant }\end{array}$ & $\begin{array}{l}\text { Negative } \\
\text { Significant }\end{array}$ & $\begin{array}{l}\text { Negative } \\
\text { Significant }\end{array}$ & Negative & $\begin{array}{l}\text { Negative } \\
\text { Significant }\end{array}$ \\
\hline $\begin{array}{c}\text { Dummy } \\
2003\end{array}$ & Negative & Positive & Negative & $\begin{array}{c}\text { Positive } \\
\text { Significant }\end{array}$ & $\begin{array}{c}\text { Positive } \\
\text { Significant }\end{array}$ & Positive \\
\hline $\begin{array}{c}\text { Dummy } \\
2004\end{array}$ & Negative & Positive & Negative & Positive & Positive & Negative \\
\hline $\begin{array}{l}\text { Dummy } \\
2005\end{array}$ & Negative & Positive & $\begin{array}{l}\text { Negative } \\
\text { Significant }\end{array}$ & Positive & Positive & $\begin{array}{l}\text { Negative } \\
\text { Significant }\end{array}$ \\
\hline $\begin{array}{c}\text { Dummy } \\
2006\end{array}$ & Positive & Positive & Negative & Negative & Positive & $\begin{array}{l}\text { Negative } \\
\text { Significant }\end{array}$ \\
\hline $\begin{array}{c}\text { Dummy } \\
2007\end{array}$ & Negative & Positive & Negative & Negative & Positive & $\begin{array}{l}\text { Negative } \\
\text { Significant }\end{array}$ \\
\hline $\begin{array}{c}\text { Dummy } \\
2008\end{array}$ & Positive & Positive & Negative & Positive & Positive & $\begin{array}{l}\text { Negative } \\
\text { Significant }\end{array}$ \\
\hline $\begin{array}{c}\text { Dummy } \\
2009\end{array}$ & Negative & Positive & $\begin{array}{l}\text { Negative } \\
\text { Significant }\end{array}$ & $\begin{array}{c}\text { Positive } \\
\text { Significant }\end{array}$ & $\begin{array}{c}\text { Positive } \\
\text { Significant }\end{array}$ & Negative \\
\hline
\end{tabular}


Regression results with the figures of $\mathrm{F}$ (ANOVA), $\mathrm{R}^{2}$, adjusted $\mathrm{R}^{2}$ and regression coefficients for independent variables including time dummies are indicated in details in Table 12.

Similar to previous models, profitability is negatively and significantly related to leverage, except for short-term leverage at book value. The regression coefficients of size are positive for gearing ratios and they are significant for total and long-term leverage at market value. Likely Model C, growth measure has negative and also significant relationships with total and long-term leverages, while it has positive relationship with short-term leverage at book value. Contrary to growth, tangibility is positively and significantly correlated to all types of leverage except for short-term. Similarly to all models, non-debt tax shield has reverse relationships with leverage. As expected, volatility and liquidity are negatively correlated to all leverage figures.

Surprisingly, time dummies have generally insignificant influence on leverage. The relations and correlation signs are inconsistent for time dummy variables. As seen in Table 11, Model D indicates insignificant time-specific effects. It needs a further extensive investigation to observe its influence. 
Table 12: Regression results of Model D for total debt ratio (TDBV), long-term debt ratio (LDBV), short-term debt ratio (SDBV) at book value and total debt ratio (TDMV), long-term debt ratio (LDMV) and short-term debt ratio (SDMV) at market value.

\begin{tabular}{|c|c|c|c|c|c|c|c|c|c|c|c|c|c|c|c|c|c|c|}
\hline & \multicolumn{3}{|c|}{ TDBV } & \multicolumn{3}{|c|}{ LDBV } & \multicolumn{3}{|c|}{ SDBV } & \multicolumn{3}{|c|}{ TDMV } & \multicolumn{3}{|c|}{ LDMV } & \multicolumn{3}{|c|}{ SDMV } \\
\hline $\mathbf{F}$ & \multirow{2}{*}{\multicolumn{3}{|c|}{$\begin{array}{c}25.92 \\
0.20\end{array}$}} & \multirow{2}{*}{\multicolumn{3}{|c|}{$\begin{array}{c}23.10 \\
0.18\end{array}$}} & \multicolumn{3}{|c|}{11.08} & \multicolumn{3}{|c|}{53.26} & \multicolumn{3}{|c|}{47.60} & \multicolumn{3}{|c|}{13.50} \\
\hline $\mathbf{R}^{2}$ & & & & & & & \multirow{3}{*}{\multicolumn{3}{|c|}{$\begin{array}{l}0.07 \\
0.09 \\
0.00\end{array}$}} & \multirow{3}{*}{\multicolumn{3}{|c|}{$\begin{array}{l}0.34 \\
0.33 \\
0.00\end{array}$}} & \multirow{3}{*}{\multicolumn{3}{|c|}{$\begin{array}{l}0.33 \\
0.21 \\
0.00\end{array}$}} & \multirow{3}{*}{\multicolumn{3}{|c|}{$\begin{array}{l}0.12 \\
0.11 \\
0.00\end{array}$}} \\
\hline Adj $R^{2}$ & \multicolumn{3}{|c|}{0.19} & \multicolumn{3}{|c|}{0.18} & & & & & & & & & & & & \\
\hline Signif. & & 0.00 & & & 0.00 & & & & & & & & & & & & & \\
\hline & Beta & $t$ & Sig & Beta & $t$ & Sig & Beta & $t$ & Sig & Beta & $\mathbf{t}$ & Sig & Beta & $t$ & Sig & Beta & $t$ & Sig \\
\hline Constant & 0.18 & 3.97 & 0.00 & 0.11 & 2.58 & 0.01 & 0.07 & 4.61 & 0.00 & 0.07 & 1.71 & 0.09 & 0.03 & 0.68 & 0.50 & 0.04 & 3.19 & 0.00 \\
\hline Profitability & -0.10 & -4.04 & 0.00 & -0.11 & -4.50 & 0.00 & 0.03 & 1.03 & 0.30 & -0.27 & -11.9 & 0.00 & -0.25 & -11.0 & 0.00 & -0.12 & -4.56 & 0.00 \\
\hline Size & 0.07 & 2.59 & 0.01 & 0.06 & 2.28 & 0.02 & 0.03 & 1.04 & 0.30 & 0.12 & 4.92 & 0.00 & 0.10 & 4.31 & 0.00 & 0.08 & 2.78 & 0.01 \\
\hline Growth & -0.07 & -2.90 & 0.00 & -0.09 & -3.59 & 0.00 & 0.05 & 1.82 & 0.07 & -0.10 & -4.34 & 0.00 & -0.10 & -4.45 & 0.00 & -0.02 & -0.70 & 0.49 \\
\hline Tangibility & 0.29 & 10.45 & 0.00 & 0.32 & 11.4 & 0.00 & -0.05 & -1.76 & 0.08 & 0.37 & 14.49 & 0.00 & 0.40 & 15.20 & 0.00 & -0.01 & -0.46 & 0.65 \\
\hline NDTS & -0.08 & -2.72 & 0.01 & -0.06 & -2.19 & 0.03 & -0.06 & -1.88 & 0.06 & -0.10 & -3.98 & 0.00 & -0.09 & -3.56 & 0.00 & -0.04 & -1.24 & 0.21 \\
\hline Volatility & -0.13 & -5.00 & 0.00 & -0.12 & -4.40 & 0.00 & -0.06 & -2.29 & 0.02 & -0.12 & -5.14 & 0.00 & -0.12 & -4.75 & 0.00 & -0.06 & -2.02 & 0.04 \\
\hline Liquidity & -0.18 & -6.97 & 0.00 & -0.11 & -4.03 & 0.00 & -0.26 & -9.36 & 0.00 & -0.11 & -4.82 & 0.00 & -0.06 & -2.42 & 0.02 & -0.21 & -7.78 & 0.00 \\
\hline D_2003 & 0.00 & -0.12 & 0.91 & 0.00 & 0.08 & 0.94 & -0.02 & -0.60 & 0.55 & 0.10 & 3.36 & 0.00 & 0.09 & 3.16 & 0.00 & 0.04 & 1.13 & 0.26 \\
\hline D_2004 & -0.03 & -0.83 & 0.41 & 0.00 & 0.04 & 0.97 & -0.09 & -2.68 & 0.01 & 0.03 & 0.95 & 0.34 & 0.06 & 1.91 & 0.06 & -0.09 & -2.64 & 0.01 \\
\hline D_2005 & -0.02 & -0.65 & 0.52 & 0.02 & 0.47 & 0.64 & -0.11 & -3.36 & 0.00 & 0.01 & 0.39 & 0.70 & 0.04 & 1.46 & 0.14 & -0.10 & -3.03 & 0.00 \\
\hline D_2006 & 0.00 & 0.04 & 0.97 & 0.03 & 0.78 & 0.44 & -0.08 & -2.24 & 0.03 & -0.02 & -0.71 & 0.48 & 0.01 & 0.31 & 0.76 & -0.11 & -3.16 & 0.00 \\
\hline D_2007 & -0.01 & -0.16 & 0.87 & 0.03 & 0.76 & 0.45 & -0.10 & -2.80 & 0.01 & -0.04 & -1.43 & 0.15 & 0.00 & -0.08 & 0.93 & -0.15 & -4.23 & 0.00 \\
\hline D_2008 & 0.01 & 0.16 & 0.87 & 0.04 & 1.07 & 0.28 & -0.09 & -2.73 & 0.01 & 0.01 & 0.19 & 0.85 & 0.04 & 1.35 & 0.18 & -0.11 & -3.35 & 0.00 \\
\hline D_2009 & -0.03 & -1.01 & 0.31 & 0.02 & 0.53 & 0.60 & -0.16 & -4.65 & 0.00 & 0.13 & 4.25 & 0.00 & 0.16 & 5.42 & 0.00 & -0.09 & -2.66 & 0.01 \\
\hline
\end{tabular}




\section{Findings}

This chapter includes seven subsections such as profitability, size, growth, tangibility, non-debt tax shield, volatility and liquidity. In these sections, results, as investigated in chapter four, from different regression models will be incorporated with past empirical studies results and capital structure theories.

\subsection{Profitability}

Profitability is measured as by ratio of EBITDA to total assets. The regression results of models have shown that profitability is negatively related to leverage except for shortterm debt ratio and it is significant for leverage ratios at market value. Thus, the hypothesis H1 holds true and profitable companies do not prefer higher ratio of debt, even the potential bankruptcy risk becomes lower with the high profit figures. These results are supported by the pecking order theory. According to pecking order theory, companies which are profitable prefer retained earnings as a primary source of financing new investments. This finding implies that profitable companies prefer internal financing rather than external financing. On the other hand, the negative sign of profitability does not support the trade off theory. Trade off theory suggest that companies with the figures of high profit tend to have higher leverage and more taxable income to shield (Barclay and Smith, 2005). Therefore, this theory fails to prove why profitable companies have relatively less debt ratio. Also the results are in line with the findings of past studies of Gaud et al. (2005), Ozkan (2001) and Rajan and Zingales (1995).

Unexpectedly, there is positive relationship between profitability and leverage for both short-term book value debt ratio in Model A and Model C. Jensen (1986) states that profitability might be positively related to leverage. The interpretation of this result

might be suppliers of debt (banks and financial institutions) are more likely to lend to companies which have high profit figures (Ozkan, 2001).

\subsection{Size}

The proxy of natural logarithm of sales is used for size. The regression result of all models proves that size is positively related to all forms of leverage ratio. Therefore the hypothesis (H2A, H2B and $\mathrm{H} 2 \mathrm{C}$ ) which claim there is a positive relationship between 
size and total, long-term and short term leverage, hold true. The results illustrate that the bigger the company in terms of sales, the larger amount of debt it has in its capital structure. This finding is consistent with static trade off theory, as mention in literature review. The risk of bankruptcy for larger a company is less than smaller a company. The reason behind this could be, larger companies 'too big to fail', since they operate in large scales and more diversified. As a result, small companies tend to borrow less than larger ones.

It is worth to make note that in Model A and Model B, for several years the relationship between size and short-term leverage at book value and market value has negative sign. In Model C, where the size is averaged over the period 2002 to 2004, and Model D, the relationship between size and short-term debt is positive. The explanation behind this might be smaller companies tend to employ more short-term debt rather than long-term debt in their capital structure. In addition to this, Rajan and Zingales (1995) suggest that the effect of size on short-term leverage is unclear. Although the hypothesis $\mathrm{H} 2 \mathrm{C}$ holds true, detailed analysis for size measure is necessary.

The results of three models support the findings of empirical studies of Ozkan (2001), Gaud et al. (2005) and Gajurel (2005).

\subsection{Growth Opportunity}

Growth is proxied as market to book ratio in this study. In Model A the results differ according to type of leverage. In Model B, growth is negatively related to leverage. In Model C, there is negative relationship between growth and total debt and long-term debt ratio, while this relationship is positive for short-term debt ratios (both market and book value). Lastly in Model $\mathrm{D}$, growth opportunity is significantly and negatively related to leverage except for short-term leverage. Practically, all is taken into consideration; there is negative relationship between growth and leverage and therefore the hypothesis $\mathrm{H} 3$ holds true, even though these findings does not prove any expressive assumption.

The results show that changes in natural logarithm of sales have no meaningful effects on growth. In consonance with the results, companies with high growth rates are more likely to have higher cost of bankruptcy and less amount of debt in capital structure. However, this finding is consistent with the pecking order theory. According to this 
theory, the company prefers retained earnings as first source of financing itself instead of debt. Therefore there is inverse relationship between growth and leverage.

Also Ozkan (2001) explains this relationship that 'it stems from the tendency of firms to issue stock when their stock price is high relative to earnings or book value' and Rajan and Zingales (1995) further states that 'this implies the negative correlation between leverage and market to book ratio is driven largely by firms that issue significant amounts of equity'.

\subsection{Asset Tangibility}

The proxy for tangibility is taken as ratio of fixed asset to total assets. The results from regression indicate that there is mix correlation between tangibility and leverage types. In Model A, Model B, Model C and Model D, asset structure is positively related to total and long-term gearing and statistically significant. Contrary, it is negatively correlated to short-term gearing at both book and market value. Hence, the hypothesis H4A and H4B which claim positive correlation between tangibility and total and long-term leverage hold true.

However, the results regarding the positive correlation for short-term leverage rejects the hypothesis H4C and this finding is line with studies of Bevan and Danbolt (2000) and Psillaki and Daskalakis (2008).

The findings are consistent with the theory, which suggests companies having higher collateral assets are more likely to have high level of debt ratios. The explanation behind this is that tangible asset is easy to collateralize and therefore it decrease the agency cost of debt (Rajan and Zingales, 1995). Besides, the results are in alignment with the agency cost theory, since debt providers claims securities as collateral to put them in more secure position.

The asset structure of companies contributes crucially to the variation in leverage and this evidence agrees that companies are more likely to employ long-term debt for fixed assets and short-term debt for current assets. Also studies of Bennett and Donnelly (1993), Rajan and Zingales (1995) and Gaud et al. (2003) have found evidences that support this correlation. 


\subsection{Non-debt Tax Shield}

Non-debt tax shield is proxied as ratio of annual depreciation to total assets. The results from Model A, Model B, Model C and Model D are in consistent with each other. The results illustrate that non-debt tax shield and all forms of leverage are correlated negatively, although there are evidence of positive correlation for a few years in Model A and Model B. In general, the hypothesis H5 holds true according to findings of this empirical study, although the results are not significant for several years.

This finding is in line with static trade-off theory. Companies that have higher non-debt tax shields, tend to have less long-term debt ratio rather than other companies.

It is worth to make note that the relations between this variable and leverage are more robust under the market value rather than book value. In addition, the findings are consistent with past empirical studies such as, Wald (1999), Ozkan (2001), Gaud et Al (2005) and Gajurel (2005).

\subsection{Volatility}

Standard deviation of EBITDA has been takes as a proxy of volatility and the results indicate ambiguous relation between this variable and leverage.

In Model $\mathrm{A}$ and Model $\mathrm{B}$, the findings illustrate that volatility is negatively related to leverage and this relation is significant under the short-term leverage at book value. In Model D, the relationship between volatility and all types of leverage is negative and significant.

The theory states that companies that have high level of operation volatility tend to have low level of debt ratio (Myers, 2001). Also Psillaki and Daskalakis (2008) study support this finding.

On the other hand, the results from Model $\mathrm{C}$ shows that there is positive relation between volatility and three types of leverage at book value, while there is negative relation for volatility for leverages at market value. This inconsistency may arise from using averaged figures for different period of time in Model C. The positive relation between this variable and leverage at book value supports the theory which states companies that are exposed to high market risk are expected to have high level of leverage. Moreover, the study of Bennett and Donnelly (1993) and Oztekin (2009) support this evidence. 
In general, the hypothesis H6 holds true, even though there are some inconsistencies.

\subsection{Liquidity}

The ratio of current assets to current liabilities has been used as a proxy of liquidity. All the results from Model A, Model B, Model C and Model D are in line with each other and liquidity of companies contributes significantly to the variation in leverage.

All these results illustrate that there is significant negative relationships between liquidity and all types of leverage. Therefore, the hypothesis $\mathrm{H} 7$ does hold true and it is noteworthy that the outcomes of Model C and Model D are more robust than other models.

The results are in consistent with the theory of liquidity level of companies implies lower level of leverage. According to Ozkan (2001), this inverse relation may arise from potential conflicts between shareholders and debt holders of the company. Namely, companies with high level of liquidity have more liquid assets and hold less amount of debt which results in lower leverage. 


\section{Conclusion}

The final section of this paper consists of the summary and reviews previous section's findings in consideration of capital structure theories and empirical researches. The limitations of study and recommendation for further researches are also presented in this section.

This research in general aims to examine the patterns and possible capital structure determinants. The main objective is to investigate the relationships between leverage ratios and firm-level determinants (profitability, size, growth opportunities, asset tangibility, non-debt tax shield, volatility and liquidity). This research covers 202 listed UK companies from FTSE 250 for the time period from 2002 to 2009.

Four different models are examined and the results generally show that there are negative relationships between leverage and profitability, growth, non-debt tax shield, volatility and liquidity, while there are positive relationships between leverage ratios and size and asset tangibility. Profitability, asset tangibility and liquidity are generally significantly related to leverage and these correlations are more evident in terms of leverage at market value. The unobserved time variant effects are represented by time dummies in Model D and time dummies have not significant influence on leverage. In other words, unobserved time variant effects have no determining influence for listed UK companies.

In general, the researcher finds that the results are much significant and successful, when either total or long-term leverage is the dependent variable. This evidence demonstrates that total and long-term leverage are more representative of companies' capital structure than short-tem leverage. Also the researcher finds that the regression results are more significant when the market value of equity is used as proxy of leverage than book value of equity. It is noteworthy to highlight that total leverage at market value of equity is the most important dependent variable as a proxy of capital structure, followed by long-term leverage at market value of equity.

As mentioned in previous chapter, regression results are consistent with different capital structure theories. The negative sign of association between profitability and total and long-term debt supports the pecking order theory. However the relationship between size and leverage supports the static trade off theory. The positive sign of correlations 
between tangibility and long-term leverage are consistent with agency theory. In addition to this, the negative association between non-debt tax shield and leverage supports static trade off theory.

Also the past papers, as mention fully in findings chapter, found evidences which support different capital structure theories. For instance, Gaud et al. (2005) find negative correlation between profitability and leverage, whilst Jensen (1986) supports positive relationship between them.

To sum things up, although there are some contradictions and inconsistencies between capital structure theories, they complement each other to determine and verify the relationships between leverage and firm-level determinants.

\subsection{Limitations of Study}

Several limitations were noted in related to this research which is noteworthy to be underlined. First of all time constrain was important limitation for this research. The time limited the sample size (number of companies) and period of study. Number of companies would have been raised more than 202 and not only listed UK companies but also unlisted companies could have been incorporated in this research. Time period of this research could have been expanded to have more consistent and robust results.

Secondly, the imperfect data was another limitation for this research. After collecting data from secondary sources, some missing figures are detected. Hence the final sample size has been decreased to 202 companies. Moreover, where possible, some missing values of companies replaced with their mean values and possible it may cause to produce imprecise and distorted data. Besides, since this research study is based on cross-section data for the purpose of this paper, the data may not present the changes in assets and debts over time.

Thirdly, only limited numbers of proxies for are used for both dependent and independent variables, due to limited amount of time. Some alternative proxies could have been taken into take account to produce more reliable and robust results.

Last but not least, the potential endogeneity of capital structure is another limitation of this study, as a shortcoming of OLS method which used in this research study (Maghyereh, 2005). Moreover, the dynamic effect of capital structure is neglected. 


\subsection{Recommendation for Further Research}

Taking into consideration more alternative proxy measures for independent variables can expand this empirical study. As mention in previous subsection, using different proxies would enable to produce more reliable and accurate results.

Only companies from FTSE 250 are selected for this research study. Although FTSE 250 companies represent more than $80 \%$ of the UK economy, it can not present of the entire population. Therefore sample size of further research could be extended with unlisted and small-medium companies for more comprehensive investigation. Also adding industry classification to regression models as dummy variables would be helpful to examine the relationships in terms of industry segment.

The time period of this study is set for only 8 years (2002 - 2009), due to time limitations as mentioned above. The further research could extend this period of time and it leads to examining capital structure over long time period to produce more reliable and accurate results.

Final Word Count $-13,629$ words 


\section{References}

Abor, J. (2008) 'Determinants of Capital Structure of Ghanaian Firms', African Economic Research Consortium, [Online] Available at: http://ideas.repec.org/p/aer/rpaper/rp_176.html (Accessed 2/8/2010)

Arnold, G. (2008) Corporate Financial Management. $4^{\text {th }}$ edition. Harlow: Financial Times Prentice Hall.

Barclay, M. and Smith, C.W. (2005) 'The Capital Structure Puzzle: Another Look at the Evidence', Journal of Applied Corporate Finance, 12, 1, 8- 20 [Online] Available at: http://www3.interscience.wiley.com/journal/119086223/abstract (Accessed 1/6/2010)

Bauer, P. (2004) 'Determinants of Capital Structure Empirical Evidence from the Czech Republic', Czech Journal of Economics and Finance, 54, pp. 1-2.

Bennett, M. and R. Donnelly (1993), 'The Determinants of Capital Structure: Some UK Evidence', British Accounting Review, Vol. 25, pp. 43-59.

Berk, J. and DeMarzo, P. (2007) Corporate Finance. Pearson International Edition: Addison Wesley.

Bevan, A.A. and Danbolt, J. (2000) 'Dynamics in the Determinants of Capital Structure in the UK', Working Paper No. 2000-9, [Online] Available at: http://papers.ssrn.com/sol3/papers.cfm?abstract_id=233551 (Accessed 1/6/2010)

Bevan, A.A. and Danbolt, J. (2002) 'Capital structure and its determinants in the United Kingdom - A decompositional analysis', Applied Financial Economics, 12 (3), pp. 159170.

Bevan, A.A. and Danbolt, J. (2004) 'Testing for inconsistencies in the estimation of UK capital structure determinants', Applied Financial Economics 14 (1), pp. 55-66.

Brinkhuis, S. and Maeseneire W. (2009) 'What derives leverage in leveraged buyouts? An analysis of European [Online] Available at: http://papers.ssrn.com/sol3/papers.cfm?abstract_id=1343871 (Accessed 7/8/2010)

Céspedes, J., González, M. and Molina, C. (2010) 'Ownership and capital structure in Latin America', Journal of Business Research, 63 pp. 248-254

Chang, C., Lee, A. and Lee, C. (2008) 'Determinants of capital structure choice: A structural equation modeling approach', The Quarterly Review of Economics and Finance 49 pp. 197-213

Chen, J. J. (2003) 'Determinants of capital structure of Chinese-listed companies', Journal of Business Research 57, pp.1341- 1351. 
Dragota, M. And Semenescu, A. (2008) 'A Dynamic Analysis of Capital Structure Determinants. Empirical Results for Romanian Capital Market', [Online] Available at: http://ideas.repec.org/a/agr/journl/v4(521)y2008i4(521)p65-80.html(Accessed 6/8/2010)

Easterbrook, F. (1984) 'Two-Agency Cost Explanations of Dividends', American Economic Review, Vol. 74, pp. 650-659.

Eriotis, N., Vasiliou, D. \& Ventoura-Neokosmidi, Z. (2007) 'How firm characteristics affect capital structure: an empirical study', Managerial Finance, 33 (5), pp. 321-331.

Gajurel, D. P. (2005) 'Capital Structure Management in Nepalese Enterprises', Master's Degree Thesis, Kathmandu: Faculty of Management, Tribhuvan University.

Gaud, P., E. Jani, M. Hoesli and A. Bender (2005), 'The Capital Structure of Swiss Companies: An Empirical Analysis using Dynamic Panel Data', European Financial Management, Vol. 11, pp. 51-69.

Harris, M. and Raviv, A. (1991) 'The Theory of Capital Structure', The Journal of Finance, 46, 1, 297-355 [Online] Available at: http://www.jstor.org/stable/pdfplus/2328697.pdf (Accessed 2/6/2010)

Jensen, M. (1986) 'Agency Costs of Free Cash Flow, Corporate Finance and Takeovers', The American Economic Review, 76(2), pp. 323-329 [Online] Available at: http://www.ecsocman.edu.ru/images/pubs/2007/10/25/0000314524/jensen_agency_costs _1986.pdf (Accessed 1/6/2010)

Jensen, M. And Meckling, W. (1976) 'Theory of The Firm: Managerial Behaviour, Agency Costs and Ownership Structure', Journal of Financial Economics, 3(4), pp.305360 [Online] Available at: ies.fsv.cuni.cz/default/file/download/id/7770 (Accessed $2 / 6 / 2010)$

Kester, C.W. (1986), 'Capital and Ownership Structure: A Comparison of United States and Japanese Manufacturing Corporations', Financial Management, Vol. 15, pp. 97-113.

Kraus, A. and R. Litzenberger (1973) 'A State-Preference Model of Optimal Financial Leverage', Journal of Finance, Vol. 28, pp. 911-922.

Lewis-Beck, M (1993) Regression Analysis, Beverley Hills, CA: Sage.

Liu, Y., Ren, J. \& Zhuang, Y. (2009) 'An Empirical Analysis on the Capital Structure of Chinese Listed IT Companies', International Journal of Business Management, 4 (8), pp.46-51.

Lööf, H. (2004) 'Dynamic optimal capital structure and technical change', Structural Change and Economic Dynamics, 15(4), pp 449-468 
Maghyereh, A. (2005) 'Dynamic Capital Structure: Evidence from the Small Developing Country of Jordan', Journal of Economics and Management 13 (1).

Miller, M. (1977) 'Debt or Taxes', The Journal of Finance, 32 (2), pp. 261-275 [Online] Available at: http://www.jstor.org/stable/pdfplus/2326758.pdf (Accessed 2/6/2010)

Miller, M. (1988) 'The Modigliani-Miller Propositions After Thirty Years', The Journal of Economic Perspectives, 2 (4), pp. 99-120 [Online] Available at: http://links.jstor.org/sici?sici=08953309\%28198823\%292\%3A4\%3C99\%3ATMPATY \%3E2.0.CO\%3B2-V (Accessed 1/6/2010)

Modigliani, F. and Miller, M. (1958) 'The Cost of Capital, Corporation Finance and Theory of Investment', The American Economic Review, 48(3), pp. 261-297 [Online] Available at: http://www.jstor.org/stable/1809766 (Accessed 1/6/2010)

Modigliani, F. and Miller, M. (1963) 'Corporate income taxes and the cost of capital: a correction', The American Economic Review, 53(3), pp. 433-443 [Online] Available at: http://www.jstor.org/stable/1809167 (Accessed 1/6/2010)

Myers, S.C. (1984) 'The Capital Structure Puzzle', Journal of Finance, Vol. 39, pp. $575-592$.

Myers, S.C. and N.S. Majluf (1984) 'Corporate Financing and Investment Decisions When firms Have Information that Investors Do not Have', Journal of Financial Economics, Vol. 13, pp. 187-221.

Myers, S.C. (2001) 'Capital Structure', Journal of Economic Perspective, Vol. 15, pp. 81-102

Psillaki, M. and Daskalakis, N. (2004) 'Are the Determinants of Capital Structure Country or Firm Specific? [Online] Available at: http://ssrn.com/abstract $=1341860$ (Accessed 1/6/2010)

Rajan, R. and Zingales L. (1995) 'What Do We Know about Capital Structure? Some Evidence from International Data', Journal of Finance, Vol. 50, pp. 1421-1460.

Ozkan, A. (2001) "Determinants of Capital Structure and Adjustment to Long Run Target: Evidence from UK Company Panel Data", Journal of Business Finance and Accounting, Vol. 28, pp. 175-198.

Oztekin, O. (2009) 'Capital Structure Decisions around the World: Which Factors are Reliably Important' [Online] Available at: http://ssrn.com/abstract=1464471 (Accessed 2/8/2010) 
Ramachandran, A. and Packkirisamy, V (2010) 'The Impact of Firm Size on Dividend Behaviour, A Study With Reference to Corporate Firms across Industries in India', [Online] Available at: http://ideas.repec.org/a/mgt/youmgt/v8y2010i1p049-078.html (Accessed 10/8/2010)

Ramlall, I. (2009) 'Determinants of Capital Structure Among Non-Quoted Mauritian Firms Under Specificity of Leverage: Looking for a Modified Pecking Order Theory', International Research Journal of Finance and Economics, 31, pp. 83-92

Shah, A. and Hijazi, T. (2004) 'The Determinants of Capital Structure of Stock Exchange-listed Non-Financial firms in Pakistan', The Pakistan Development Review 43: 4 Part II pp. 605-618

Song, H. (2005) 'Capital Structure Determinants An Empirical Study of Swedish Companies', The Royal Institute of technology Centre of Excellence for Science and Innovation Studies, January 2005.

Titman, S. and Wessels, R. (1988) 'The Determinants of Capital Structure choice', Journal of Finance, 43, pp.1-19.

Vasiliou, D. and Daskalakis, N. (2009) 'Institutional characteristics and capital structure: A cross-national comparison', Global Finance Journal, 19, pp. 286-306

Wald, J. (1999) 'How Firm Characteristics Affect Capital Structure: An International Comparison', Journal of Financial Research, Vol. 22, pp. 161-187.

Warner, J., (1977) 'Bankruptcy Costs: Some Evidence', The Journal of Finance, 26, 2, 337-347 [Online] Available at: http://www.jstor.org/stable/pdfplus/2326766.pdf (Accessed 2/6/2010) 


\section{Appendices}

\section{Appendix 1: List of companies}

\begin{tabular}{|c|c|c|}
\hline Name & DS Mnemonic & DS Code \\
\hline AGGREKO & AGK & 892907 \\
\hline AMEC & AMEC & 901788 \\
\hline ANGLO AMERICAN & AAL & 903076 \\
\hline ANTOFAGASTA & ANTO & 926288 \\
\hline ARM HOLDINGS & ARM & 679297 \\
\hline ARRIVA & ARI & 914151 \\
\hline ASHTEAD GROUP & AHT & 906045 \\
\hline ASSOCIATED BRIT.FOODS & $A B F$ & 900825 \\
\hline ASTRAZENECA & AZN & 319608 \\
\hline ATKINS (WS) & ATK & 882044 \\
\hline AUTONOMY CORP. & $A U$. & 269281 \\
\hline AVEVA GROUP & AVV & 882839 \\
\hline BABCOCK INTL. & BAB & 900552 \\
\hline BAE SYSTEMS & BA. & 901419 \\
\hline BALFOUR BEATTY & BBY & 900494 \\
\hline BARR (AG) & BRAG & 914023 \\
\hline BARRATT DEVELOPMENTS & BDEV & 906309 \\
\hline BBA AVIATION & BBA & 900293 \\
\hline BELLWAY & BLWY & 904076 \\
\hline BERKELEY GROUP HDG.(THE) & BKG & 974117 \\
\hline BG GROUP & BG. & 911488 \\
\hline BHP BILLITON & BLT & 899188 \\
\hline BODYCOTE & BODY & 910119 \\
\hline BOVIS HOMES GROUP & BVS & 671226 \\
\hline BP & BP. & 900995 \\
\hline BRITISH AIRWAYS & BAY & 914447 \\
\hline BRITISH AMERICAN TOBACCO & BATS & 901295 \\
\hline BRITISH SKY BCAST.GROUP & BSY & 135116 \\
\hline BRITVIC & BVIC & $32480 C$ \\
\hline BROWN (N) GROUP & BRWN & 914327 \\
\hline BSS GROUP & BTSM & 900578 \\
\hline BT GROUP & BT.A & 900888 \\
\hline BTG & BGC & 139996 \\
\hline BUNZL & BNZL & 901067 \\
\hline BURBERRY GROUP & BRBY & $25968 K$ \\
\hline CABLE \& WIRELESS COMMS. & CWC & 901634 \\
\hline CAIRN ENERGY & CNE & 910146 \\
\hline CAPITA GROUP & CPI & 953830 \\
\hline
\end{tabular}




\begin{tabular}{|c|c|c|}
\hline CARILLION & CLLN & 684990 \\
\hline CARNIVAL & $\mathrm{CCL}$ & 265148 \\
\hline CARPETRIGHT & CPR & 319752 \\
\hline CENTAMIN EGYPT NPV (LON) & CEY & 257827 \\
\hline CENTRICA & CNA & 888276 \\
\hline CHARTER INTL. & CHTR & 901016 \\
\hline CHEMRING GROUP & CMRG & 914073 \\
\hline CHLORIDE GROUP & CHLD & 900930 \\
\hline COBHAM & $\mathrm{COB}$ & 904313 \\
\hline COLT GROUP & COLT & 870717 \\
\hline COMPASS GROUP & CPG & 255049 \\
\hline COMPUTACENTER & $\mathrm{CCC}$ & 679947 \\
\hline CONNAUGHT & CNT & 690266 \\
\hline COOKSON GROUP & CKSN & 900433 \\
\hline CRANSWICK & CWK & 914038 \\
\hline CRODA INTERNATIONAL & CRDA & 900476 \\
\hline DAILY MAIL 'A' & DMGT & 910716 \\
\hline DAIRY CREST & DCG & 882065 \\
\hline DANA PETROLEUM & DNX & 943973 \\
\hline DAVIS SERVICE GROUP & DVSG & 900954 \\
\hline DE LA RUE & DLAR & 901343 \\
\hline DEBENHAMS & DEB & $35793 C$ \\
\hline DIAGEO & DGE & 900251 \\
\hline DIMENSION DATA HDG. & DDT & 298320 \\
\hline DOMINO PRINTING SCIENCES & DNO & 910043 \\
\hline DOMINO'S PIZZA & DOM & 278612 \\
\hline DRAX GROUP & DRXG & $32545 \mathrm{E}$ \\
\hline DSG INTERNATIONAL & DSGI & 900906 \\
\hline EASYJET & EZJ & 280641 \\
\hline ELECTROCOMP. & ECOM & 904690 \\
\hline ENTERPRISE INNS & ETI & 137668 \\
\hline EUROMONEY INSTL.INVESTOR & ERM & 728803 \\
\hline EXPERIAN & EXPN & 410124 \\
\hline FENNER & FENR & 900575 \\
\hline FIDESSA GROUP & FDSA & 897412 \\
\hline FILTRONA & FLTR & $31110 U$ \\
\hline FIRST GROUP & FGP & 135229 \\
\hline FORTH PORTS & FPT & 928787 \\
\hline GALIFORM & GFRM & 507530 \\
\hline GAME GROUP & GMG & 910532 \\
\hline GENUS & GNS & 296734 \\
\hline
\end{tabular}




\begin{tabular}{|c|c|c|}
\hline GKN & GKN & 900754 \\
\hline GLAXOSMITHKLINE & GSK & 900479 \\
\hline GO-AHEAD GROUP & GOG & 135565 \\
\hline GREENE KING & GNK & 900250 \\
\hline GREGGS & GREG & 952780 \\
\hline HALMA & HLMA & 910821 \\
\hline HAYS & HAS & 901164 \\
\hline HIKMA PHARMACEUTICALS & HIK & $32273 \mathrm{~L}$ \\
\hline HOMESERVE & HSV & 928782 \\
\hline HUNTING & HTG & 917509 \\
\hline ICAP & IAP & 688846 \\
\hline ICTL.HTLS.GP. & IHG & $26923 \mathrm{~V}$ \\
\hline IMAGINATION TECHNOLOGIES & IMG & 135869 \\
\hline IMI & IMI & 901704 \\
\hline IMPERIAL TOBACCO GP. & IMT & 882240 \\
\hline INCHCAPE & $\mathrm{INCH}$ & 901029 \\
\hline INFORMA & INF & 679154 \\
\hline INMARSAT & ISAT & $30877 \mathrm{H}$ \\
\hline INTERNATIONAL POWER & IPR & 928901 \\
\hline INTERTEK GROUP & ITRK & 258092 \\
\hline INVENSYS & ISYS & 905110 \\
\hline ITE GROUP & ITE & 907765 \\
\hline JD SPORTS FASHION & JD. & 882323 \\
\hline JKX OIL \& GAS & $J K X$ & 139998 \\
\hline JOHNSON MATTHEY & JMAT & 901152 \\
\hline KAZAKHMYS & KAZ & $29070 U$ \\
\hline KELLER & KLR & 135540 \\
\hline KIER GROUP & KIE & 882977 \\
\hline KINGFISHER & KGF & 940281 \\
\hline LADBROKES & LAD & 910437 \\
\hline LAIRD & LRD & 901107 \\
\hline LOGICA & LOG & 901940 \\
\hline LONMIN & LMI & 902232 \\
\hline MARKS \& SPENCER GROUP & MKS & 901207 \\
\hline MARSTON'S & MARS & 900274 \\
\hline MCBRIDE & MCB & 134982 \\
\hline MEGGITT & MGGT & 910509 \\
\hline MICHAEL PAGE INTL. & MPI & 255364 \\
\hline MICRO FOCUS INTL. & MCRO & $30857 \mathrm{U}$ \\
\hline MILLENNIUM \& CPTH.HTLS. & MLC & 870866 \\
\hline MISYS & MISY & 914192 \\
\hline
\end{tabular}




\begin{tabular}{|c|c|c|}
\hline MITCHELLS \& BUTLERS & MAB & 26923T \\
\hline MITIE GROUP & MTO & 910407 \\
\hline MORGAN CRUCIBLE & MGCR & 900408 \\
\hline MORRISON(WM)SPMKTS. & MORW & 905576 \\
\hline MOTHERCARE & MTC & 905308 \\
\hline NATIONAL EXPRESS & NEX & 301917 \\
\hline NATIONAL GRID & NG. & 870181 \\
\hline NEXT & NXT & 901203 \\
\hline PACE & PIC & 875854 \\
\hline PARTYGAMING & PRTY & $30234 N$ \\
\hline PEARSON & PSON & 914021 \\
\hline PENNON GROUP & PNN & 904391 \\
\hline PERSIMMON & PSN & 910133 \\
\hline PETROFAC & PFC & $31946 \mathrm{M}$ \\
\hline PETROPAVLOVSK & POG & 257965 \\
\hline PREMIER FARNELL & PFL & 905498 \\
\hline PREMIER FOODS & PFD & $28961 \mathrm{~T}$ \\
\hline PREMIER OIL & PMO & 900997 \\
\hline PUNCH TAVERNS & PUB & 258077 \\
\hline PZ CUSSONS & PZC & 910580 \\
\hline RANDGOLD RESOURCES & RRS & 897895 \\
\hline RANK GROUP & RNK & 900918 \\
\hline RECKITT BENCKISER GROUP & RB. & 900484 \\
\hline REDROW & RDW & 507916 \\
\hline REED ELSEVIER & REL & 901080 \\
\hline REGUS & RGU & 266577 \\
\hline RENISHAW & RSHW & 917076 \\
\hline RENTOKIL INITIAL & RENT & 906480 \\
\hline RESTAURANT GROUP & RTN & 912000 \\
\hline REXAM & REX & 901065 \\
\hline RIO TINTO & $\mathrm{RIO}$ & 901714 \\
\hline ROBERT WISEMAN DAIRIES & RWD & 135523 \\
\hline ROLLS-ROYCE GROUP & RR. & 940793 \\
\hline ROTORK & RTRK & 910649 \\
\hline ROYAL DUTCH SHELL A(LON) & RDSA & $31347 \mathrm{~F}$ \\
\hline ROYAL DUTCH SHELL B & RDSB & 900998 \\
\hline RPS GROUP & RPS & 953598 \\
\hline SABMILLER & SAB & 695504 \\
\hline SAGE GROUP & SGE & 904649 \\
\hline SAINSBURY (J) & SBRY & 926002 \\
\hline SCOT.\& SOUTHERN ENERGY & SSE & 928738 \\
\hline
\end{tabular}




\begin{tabular}{|c|c|c|}
\hline SDL & SDL & 278833 \\
\hline SENIOR & SNR & 900600 \\
\hline SERCO GROUP & SERC & 943663 \\
\hline SEVERN TRENT & SVT & 904373 \\
\hline SHANKS GROUP & SKS & 981250 \\
\hline SHIRE & SHP & 870593 \\
\hline SIG & $\mathrm{SHI}$ & 946054 \\
\hline SMITH \& NEPHEW & SN. & 900487 \\
\hline SMITH (DS) & SMDS & 910685 \\
\hline SMITHS GROUP & SMIN & 900943 \\
\hline SOCO INTERNATIONAL & SIA & 897311 \\
\hline SPECTRIS & SXS & 953203 \\
\hline SPIRAX-SARCO & SPRX & 900741 \\
\hline SPIRENT COMMUNICATIONS & SPT & 900493 \\
\hline SSL INTERNATIONAL & SSL & 914579 \\
\hline ST.JAMES'S PLACE & STJ & 882217 \\
\hline STAGECOACH GROUP & SGC & 319410 \\
\hline STHREE & STHR & $32301 X$ \\
\hline SYNERGY HEALTH & SYR & $14408 \mathrm{R}$ \\
\hline TATE \& LYLE & TATE & 900819 \\
\hline TAYLOR WIMPEY & TW. & 900345 \\
\hline TESCO & $\mathrm{TSCO}$ & 900803 \\
\hline TOMKINS & TOMK & 911258 \\
\hline TRAVIS PERKINS & TPK & 931669 \\
\hline TULLOW OIL & TLW & 506343 \\
\hline ULTRA ELECTRONICS HDG. & ULE & 882275 \\
\hline UNILEVER (UK) & ULVR & 900789 \\
\hline UNITED BUSINESS MEDIA & UBM & 901106 \\
\hline UNITED UTILITIES GROUP & UU. & 904367 \\
\hline VICTREX & VCTA & 870364 \\
\hline VODAFONE GROUP & VOD & 953133 \\
\hline VT GROUP & VTG & 943559 \\
\hline WEIR GROUP & WEIR & 900699 \\
\hline WETHERSPOON (JD) & JDW & 301861 \\
\hline WHITBREAD & WTB & 900271 \\
\hline WILLIAM HILL & WMH & 258107 \\
\hline WOLSELEY & WOS & 900764 \\
\hline WOOD GROUP (JOHN) & WG. & 258098 \\
\hline WPP & WPP & 926119 \\
\hline XSTRATA & XTA & $15322 M$ \\
\hline YELL GROUP & YELL & $27237 R$ \\
\hline
\end{tabular}

